US Army Corps

of Engineers .

Prepared for the U.S. Army Corps of Engineers, Portland District,

under an Interagency Agreement with the U.S. Department of Energy

Contract DE-AC05-76RL01830

\title{
Hydroacoustic Evaluation of Overwintering Summer Steelhead Fallback and Kelt Passage at The Dalles Dam 2008-2009
}

\section{FINAL REPORT}

F Khan

GE Johnson

MA Weiland

September 2009

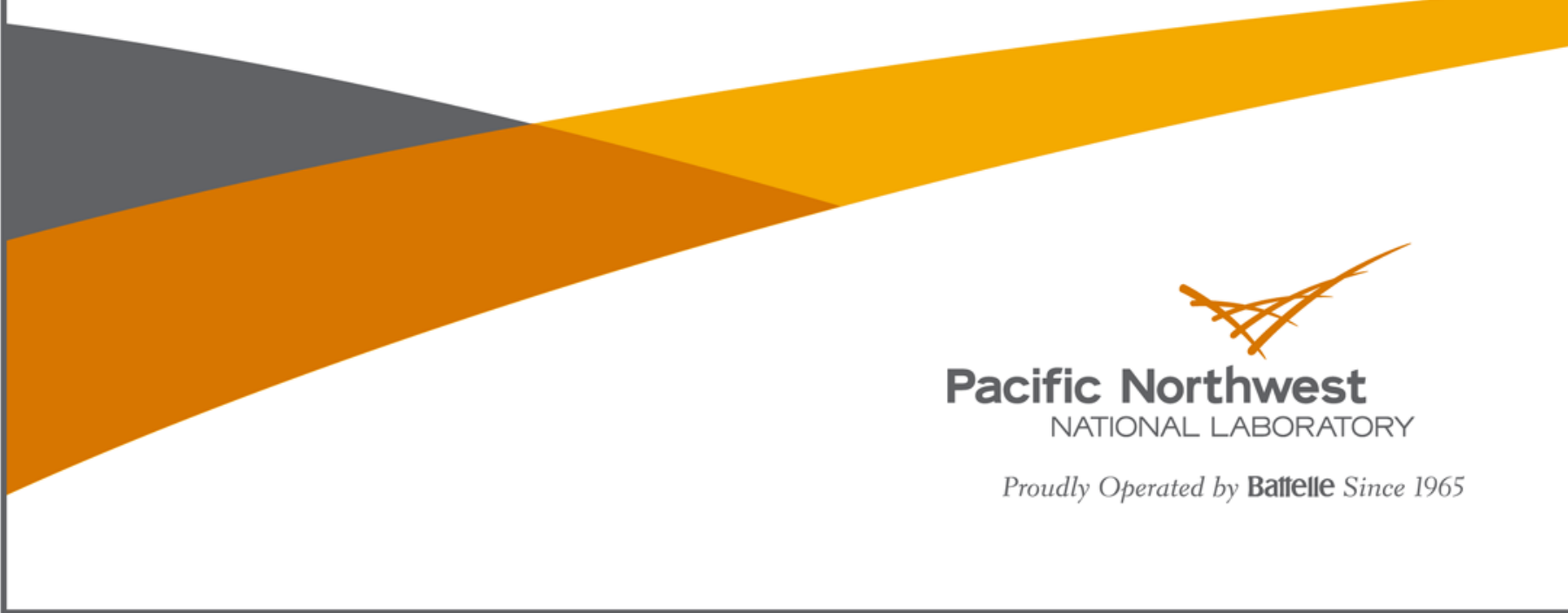




\title{
DISCLAIMER
}

This report was prepared as an account of work sponsored by an agency of the United States Government. Neither the United States Government nor any agency thereof, nor Battelle Memorial Institute, nor any of their employees, makes any warranty, express or implied, or assumes any legal liability or responsibility for the accuracy, completeness, or usefulness of any information, apparatus, product, or process disclosed, or represents that its use would not infringe privately owned rights. Reference herein to any specific commercial product, process, or service by trade name, trademark, manufacturer, or otherwise does not necessarily constitute or imply its endorsement, recommendation, or favoring by the United States Government or any agency thereof, or Battelle Memorial Institute. The views and opinions of authors expressed herein do not necessarily state or reflect those of the United States Government or any agency thereof.

\author{
PACIFIC NORTHWEST NATIONAL LABORATORY \\ operated by \\ BATTELLE \\ for the \\ UNITED STATES DEPARTMENT OF ENERGY \\ under Contract DE-AC05-76RL01830 \\ Printed in the United States of America \\ Available to DOE and DOE contractors from the \\ Office of Scientific and Technical Information, \\ P.O. Box 62, Oak Ridge, TN 37831-0062; \\ ph: (865) 576-8401 \\ fax: (865) 576-5728 \\ email: reports@adonis.osti.gov \\ Available to the public from the National Technical Information Service, \\ U.S. Department of Commerce, 5285 Port Royal Rd., Springfield, VA 22161 \\ ph: (800) 553-6847 \\ fax: (703) 605-6900 \\ email: orders@ntis.fedworld.gov \\ online ordering: http://www.ntis.gov/ordering.htm
}

This document was printed on recycled paper.

$(9 / 2003)$ 


\section{Hydroacoustic Evaluation of Overwintering Summer Steelhead Fallback and Kelt Passage at The Dalles Dam 2008-2009}

F Khan

GE Johnson

MA Weiland

September 2009

Prepared for

U.S. Army Corps of Engineers, Portland District

Under an Interagency Agreement with

the U.S. Department of Energy

Contract DE-AC05-76RL01830

Pacific Northwest National Laboratory

Richland, Washington 99352 


\section{Preface}

This study was funded as part of the Anadromous Fish Evaluation Program (AFEP), which is managed by the U.S. Army Corps of Engineers, Portland District (USACE) to support management decisions on operations of The Dalles Dam sluiceway. The AFEP study codes are ADS-00-1 (Evaluation of adult salmon and steelhead delay and fallback at dams on Snake and Columbia rivers) and ADS-P-00-6 (Evaluation of steelhead kelt passage through Columbia and Snake river dams). The study was conducted by the Pacific Northwest National Laboratory (PNNL) for the USACE, whose technical lead was David Clugston (503 808 4751). The PNNL project manager was Fenton Khan (509 371 7230). The data are archived at PNNL offices in Richland, Washington. The final version of this report is the project deliverable (PNNL Project No. 55449). 


\section{Summary}

This report presents the results of an evaluation of overwintering summer steelhead (Oncorhynchus mykiss) fallback and early out-migrating steelhead kelts downstream passage at The Dalles Dam (TDA) sluiceway and turbines during fall/winter 2008 and early spring 2009, respectively. The study was conducted by the Pacific Northwest National Laboratory (PNNL) for the U.S. Army Corps of Engineers, Portland District (USACE). Operating the sluiceway reduces the potential for hydropower production. However, this surface flow outlet may be the optimal non-turbine route for fallbacks in late fall after the sluiceway is typically closed for juvenile fish passage and for overwintering summer steelhead and kelt passage in the early spring before the start of the voluntary spill season. The goal of this study was to characterize adult steelhead spatial and temporal distributions and passage rates at the sluiceway and turbines, and their movements in front of the sluiceway at TDA to inform fisheries managers' and engineers' decision-making relative to sluiceway operations.

The study periods were from November 1 to December 15, 2008 (45 days) and from March 1 to April 9, 2009 (40 days). The study objectives were to 1) estimate the number and distribution of overwintering summer steelhead fallbacks and kelt-sized acoustic targets passing into the sluiceway and turbines at TDA during the two study periods, respectively, and 2) assess the behavior of these fish in front of sluice entrances. We obtained fish passage data using fixed-location hydroacoustics and fish behavior data using acoustic imaging.

For the overwintering summer steelhead, fallback occurred throughout the 45-day study period. We estimated that a total of 1,790 \pm 250 (95\% confidence interval) summer steelhead targets passed through the powerhouse intakes and operating sluices during November 1 to December 15, 2008. Ninety-five percent of these fish passed through the sluiceway. Therefore, without the sluiceway as a route through the dam, a number of steelhead may have fallen back through turbines. Run timing peaked in late November, but fish continued to pass the dam until the end of the study. Horizontal distribution data indicated that Sluice 1, especially sluice entrance 1-3, is the preferred route for these fish during fallback through the dam. Diel distribution for overwintering steelhead fallbacks was variable with no apparent distinct patterns. Therefore, sluiceway operations should not be based on diel distribution.

For the early spring study, overwintering summer steelhead and early out-migrating steelhead kelt downstream passage occurred throughout the 40-day study period. A total of 1,766 \pm 277 (95\% confidence interval) kelt-size targets were estimated to have passed through the powerhouse intakes and operating sluices. Ninety-five percent of these fish passed through the sluiceway. Therefore, as with steelhead fallback, not having the sluiceway as a route through the dam, a number of overwintering steelhead and kelts may use the turbines for downstream passage before the start of the spill season. Run timing peaked in late March; however, relatively large numbers of kelt-sized targets passed the dam on March 2 and March 6 (162 and 188 fish, respectively). Horizontal distribution indicated that Sluice 1, especially sluice entrance 1-3, is the preferred route for these adult salmonids as they migrate downstream through the dam. Again, no clear pattern was seen for diel distribution of overwintering steelhead and early out-migrating kelt passage.

Fish behavior of both steelhead fallbacks and kelts was that of a typical salmonid in front of a sluice entrance. Fish in front of the sluice entrance were oriented into the flow in the sluice nearfield, milling just upstream of the sill, entering into the sluiceway, or swimming upstream out into the forebay. These 
fish also moved along the face of the dam. Juvenile shad were present from the beginning of the sampling period on November 1, 2008, until mid-November. Steelhead behavior did not change in the presence of thousands of juvenile shad.

The results of this study strongly suggest that operating the TDA sluiceway for fish passage (fallbacks and kelts) during the late fall, winter, and early spring months will provide an optimal, non-turbine route for these fishes to pass the dam. Fallback of overwintering summer steelhead during late fall and winter and passage of steelhead kelt and overwintering summer steelhead during early spring are instances of the benefits of using surface flow outlets instead of turbines to pass salmonids. All 13 dams on the mainstem Columbia and Snake rivers have installed or are developing surface flow outlets to pass juvenile salmonids. Fisheries and hydrosystem managers are responsibly considering the use of these structures to protect adult salmonids from hydropower turbines. 


\section{Acknowledgments}

The authors thank the following people who contributed to this study:

- Honald Crane Services: Mike Honald and Bob Austin.

- Pacific States Marine Fisheries: Eric Fischer and Jina Kim.

- Personnel at The Dalles Dam: Miroslaw Zyndol, Robert Cordie, and staff from Operations, Electrical, and Structural and Maintenance crews.

- PNNL: Aaron Cushing, Gene Ploskey, James Hughes, Jan Slater, Julie Hughes, Kathy Lavender, Matt Wilberding, Nathan Phillips, Shon Zimmerman, Susan Ennor, Lila Andor, and Tyrell Monter.

- Precision Acoustic Systems: Alan Wirtz.

- Schlosser Machine Shop: Vincent Schlosser.

- U.S. Army Corps of Engineers, Portland District personnel: Dave Clugston, Mike Langeslay, Robert Wertheimer. 


\section{Acronyms and Abbreviations}

\begin{tabular}{ll} 
AFEP & Anadromous Fish Evaluation Program \\
cfs & cubic feet per second \\
CI & confidence interval \\
d & day(s) \\
DART & Data Access in Real Time \\
dB & decibel(s) \\
DIDSON & Dual Frequency Identification Sonar \\
ft & foot/feet \\
h & hour(s) \\
in. & inch(es) \\
kcfs & thousand cubic feet per second \\
kHz & kiloHertz \\
m & meter(s) \\
min & minute(s) \\
msl & mean sea level \\
MU & Main Unit - turbine intake \\
MW & megawatt(s) \\
NMFS & National Marine Fisheries Service \\
PAS & Precision Acoustic Systems \\
PNNL & Pacific Northwest National Laboratory \\
pps & pings per second \\
s & second(s) \\
TDA & The Dalles Dam \\
$\mu$ Pa & micro-Pascal \\
USACE & U.S. Army Corps of Engineers, Portland District \\
& \\
\hline &
\end{tabular}




\section{Contents}

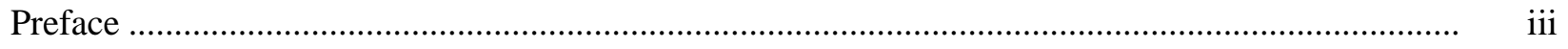

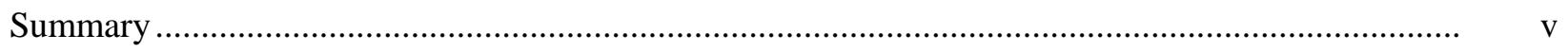

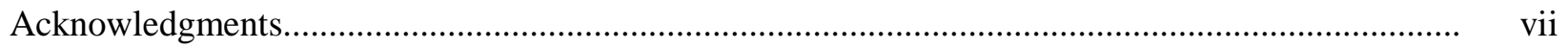

Acronyms and Abbreviations ............................................................................................... ix

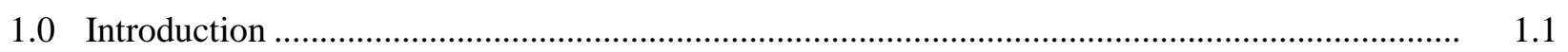

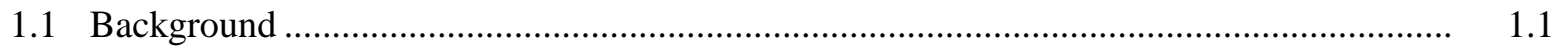

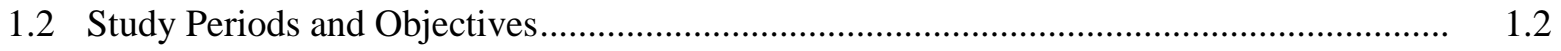

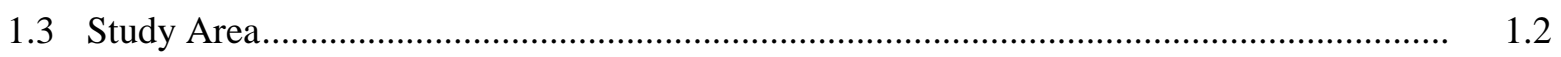

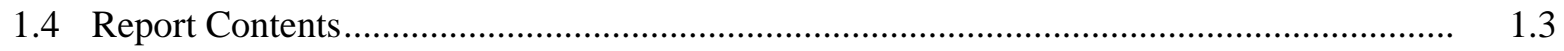

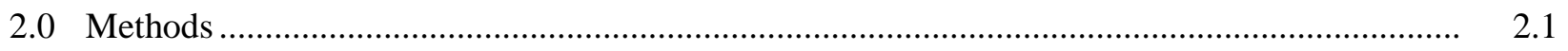

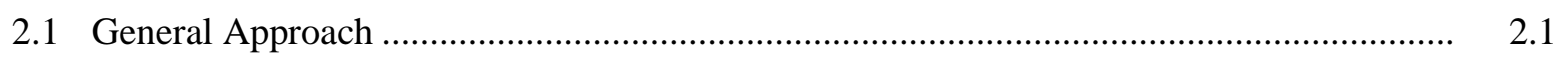

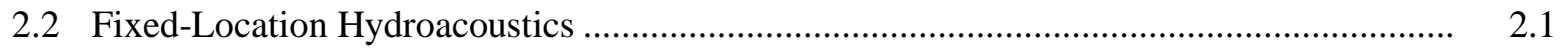

2.2.1 Hydroacoustic Systems .................................................................................. 2.1

2.2.2 Transducer Locations and Orientations............................................................ 2.2

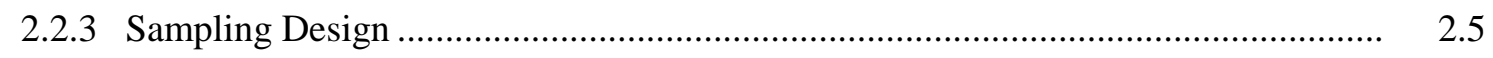

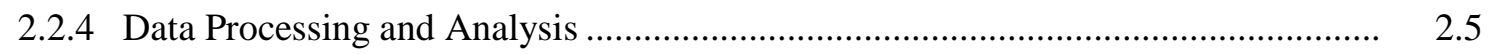

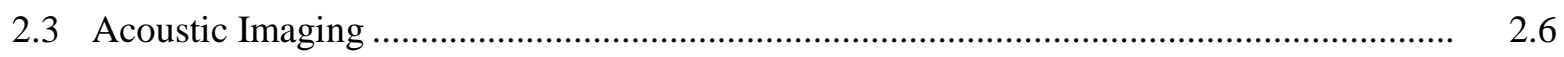

2.3.1 Sampling Locations...................................................................................... 2.7

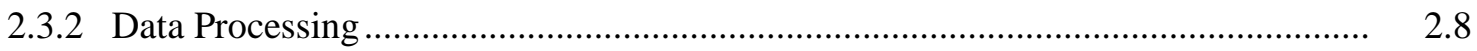

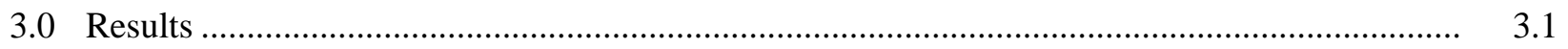

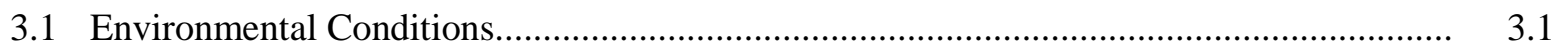

3.2 Fish Passage Evaluation ............................................................................................. 3.3

3.2.1 Overwintering Summer Steelhead Fallback......................................................... 3.3

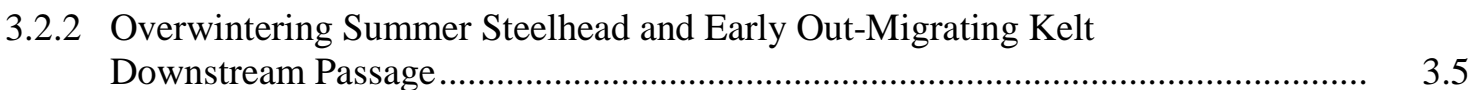

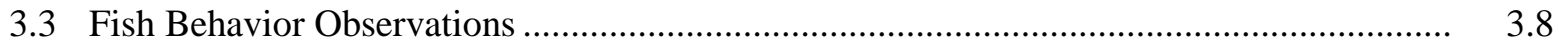

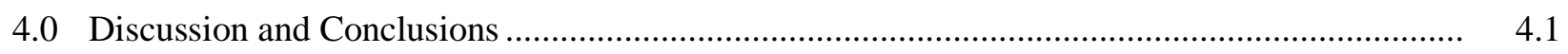

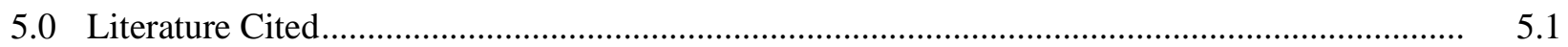




\section{Figures}

1.1 Aerial Photograph of The Dalles Dam .............................................................................

2.1 Plan View of The Dalles Dam Showing Transducer Locations ................................................ 2.2

2.2 Cross-Sectional View of a Main Unit Intake Transducer Deployment .................................... 2.3

2.3 Deployment for a Side-Looking Sluiceway Transducer Mounted on a

Steel I-Beam Attached to the Front of a Pier Nose .................................................................. 2.3

2.4 Top View of Transducer Deployment for Sluice 1 .......................................................... 2.4

2.5 Top View of Transducer Deployment for Sluice 5 ........................................................... 2.4

$2.6 \quad$ Top View of Transducer Deployment for Sluice 18 ............................................................. 2.4

$2.7 \quad$ Screen from the DIDSON Display. ................................................................................. 2.7

2.8 DIDSON Mounted to Trolley and Deployed on an I-Beam on the Front of the Pier............... $\quad 2.7$

2.9 Top View Showing the DIDSON Sampling Location at Sluice 1......................................... 2.8

3.1 Total Outflow and 10-Year Average Outflow at TDA During Fall/Winter 2008 and Early Spring 2009 .................................................................................................

3.2 Forebay Elevation and Total Sluiceway Discharge at TDA During Fall/ Winter 2008 and Early Spring 2009 ...................................................................................... $\quad 3.2$

3.3 Total Number of Overwintering Summer Steelhead Targets Passing Daily at Each Route of the Powerhouse and Sluiceway from November 1-December 15, 2008.

3.4 Horizontal Distribution of Total Passage Overwintering Summer Steelhead Targets at Each Route of the Powerhouse and Sluiceway, with Corresponding Powerhouse Intake Unit and Sluiceway Discharge, from November 1-December 15, 2008

3.5 Horizontal Distribution of Total Passage of Overwintering Summer Steelhead Targets at Each Route of the Sluiceway from November 1-December 15, 2008.

3.6 Diel Distribution of Overwintering Summer Steelhead Targets from November 1December 15, 2008.

3.7 Total Number of Overwintering Summer Steelhead and Kelt-Sized Targets Passing Daily at Each Route of the Powerhouse and Sluiceway from March 1-April 9, 2009

3.8 Horizontal Distribution of Total Passage of Overwintering Steelhead and Kelt-Sized Targets at Each Route of the Powerhouse and Sluiceway, with Corresponding Powerhouse Intake Unit Discharge, from March 1-April 9, 2009

3.9 Horizontal Distribution of Total Passage of Overwintering Steelhead and Kelt-Sized Targets at Each Route of the Sluiceway from March 1-April 9, 2009 .....

3.10 Diel Distribution of Overwintering Summer Steelhead and Kelt-Sized Targets from March 1-April 9, 2009

3.11 Adult Steelhead with Juvenile Shad During November 2008 at Sluice Entrance 1-1.............. 3.8

3.12 Yearling-Sized Salmonids During December 2008 at Sluice Entrance 1-1 .......................... 3.9

3.13 Run Timing for Juvenile Sized Fish During Late Fall 2008 ................................................ 3.10

3.14 Run Timing for Juvenile Sized Fish During Early Spring 2009 .......................................... 3.10 


\section{Tables}

2.1 Sample Locations and Spatial Sampling Intensity at The Dalles Dam in 2008/2009 ................. 2.2

2.2 Mean Target Strength Filters ..................................................................................... 2.5 


\subsection{Introduction}

This report presents the results of an evaluation of overwintering summer steelhead (Oncorhynchus mykiss) fallback and steelhead kelt downstream passage at The Dalles Dam (TDA) sluiceway and turbines during fall/winter 2008 and early spring 2009 periods, respectively. The study was conducted by the Pacific Northwest National Laboratory (PNNL) ${ }^{1}$ for the U.S. Army Corps of Engineers, Portland District (USACE). The goal of this study was to characterize adult steelhead spatial and temporal distributions and passage rates at the sluiceway and turbines, and movements in front of the sluiceway at TDA for fisheries managers and engineers to use in decision-making for sluiceway operations.

\subsection{Background}

The upstream migration of summer steelhead, an anadromous Pacific salmonid (rainbow trout), begins in spring and goes through late fall, and these salmonids overwinter in freshwater before spawning (Keefer et al. 2008). Very little information exists about steelhead behavior during winter at or near hydroelectric dams on the Columbia River (Keefer et al. 2008). These authors observed some summer steelhead overwintering within the hydrosystem before reaching spawning grounds. Some of these fish may fall back at hydroelectric dams on the Columbia River (Boggs et al. 2004). Fallback behavior is described by Reischel and Bjornn (2003) and Boggs et al. (2004) as adult salmonids straying from their normal upstream migration to spawning grounds and moving back downstream through the dams by way of turbine intakes, bypass systems, spillways, navigation locks, or other available routes. Also, during migration, some adult salmonids may travel upriver beyond their natal streams ("overshooting”) and may fall back through dams to return to said streams (Boggs et al. 2004). In a letter report to the USACE, Keefer and Peery (2007) addressed the issue of steelhead falling back at TDA during late fall and winter months. In addition, Keefer et al. (2008) recorded wintertime fallbacks at TDA. Keefer and Peery (2007) suggested that overwintering adult summer steelhead are using the TDA turbines, sluiceways, and the navigation lock as fallback routes.

After overwintering and spawning in freshwater, steelhead can migrate back downstream to the ocean in the spring. These downstream migrants, commonly referred to as kelts, may eventually return to freshwater spawning grounds to spawn again. This life history pattern is termed iteroparity. Kelts have to navigate through hydroelectric dams on their outward migration. The dams may delay migration timing and negatively impact survival of said fish (Wertheimer and Evans 2005; Wertheimer et al. 2003). As with the fallback of overwintering summer steelhead, kelts pass the dam through available routes, including turbines and sluiceways.

The National Marine Fisheries Service (NMFS) stipulated in RPA 54 of the 2008 Biological Opinion on operation of the Federal Columbia River Power System (NMFS 2008) that: “...In addition to the current sluiceway operation (generally April 1-November 30), evaluate operation of The Dalles Dam sluiceway from March 1-March 31 and from December 1-December 15 as a potential means to provide a safer fallback passage route for overwintering steelhead and kelts, implement if warranted...Investigate

\footnotetext{
${ }^{1}$ Pacific Northwest National Laboratory is operated by Battelle for the U.S. Department of Energy under Contract DE-AC05-76RL01830.
} 
surface-flow outlets during wintertime to provide safer fallback opportunity for over wintering steelhead (need will be determined by results of further research...Planning dates and voluntary operation of The Dalles Dam sluiceway may be adjusted (increased or decreased) through the adaptive management process or for research purposes."

Because steelhead are listed by the Endangered Species Act as endangered in the upper Columbia River and threatened in the Snake and mid Columbia rivers (NMFS 2004), the USACE is dedicated to providing safe and timely passage for overwintering summer steelhead fallbacks and kelts at TDA. Providing optimal, non-fatal downstream routes at dams should improve return rates of kelts (Wertheimer and Evans 2005). The USACE 2006 Fish Passage Plan included operating the TDA sluiceway until November 30 as a route for fallbacks because of concerns about these fish using the turbines as a route through the dam. Operating the sluiceway reduces the potential for hydropower production, but this surface flow outlet may be the optimal non-turbine route for overwintering fallbacks in late fall and winter (November 1 to December 15) and kelt passage in early spring (March 1 to April 15) before the start of the voluntary spill season.

\subsection{Study Periods and Objectives}

The study periods were from November 1 to December 15, 2008, and from March 1 to April 9, 2009. The study objectives were as follows:

- Estimate the number and distribution of summer steelhead fallbacks and kelt-sized acoustic targets passing into the sluiceway and turbines at TDA during the two study periods, respectively.

- Assess the behavior of these fish in front of sluice entrances.

\subsection{Study Area}

The Dalles Dam (Figure 1.1), located at river mile 192, is the second closest dam in the Federal Columbia River Power System to the Pacific Ocean. It has a 2,090-ft-long powerhouse with 22 turbine units (main units), a total generating capacity of 1,800 MW, and a total hydraulic capacity of 375 kcfs. Full pool elevation is rated at $160 \mathrm{ft}$ above mean sea level (msl) and minimum operating pool elevation is $155 \mathrm{ft}$. The normal operating pool is at elevation $158 \mathrm{ft}$. The face of the dam is $11.3^{\circ}$ off vertical. The turbine intake ceiling intersects the trash racks at elevation $141 \mathrm{ft}$. The 1380-ft-long spillway consists of 23 bays with 50 -ft wide radial gates.

The ice-and-trash sluiceway is a rectangular channel that extends the entire length of the powerhouse. Sluice entrances are $20 \mathrm{ft}$ wide. The sill at each sluice entrance is at elevation $151 \mathrm{ft}$. Water enters the sluiceway from the forebay when gates are moved off a sill. When any of the sluiceway gates are opened, water and migrating fish near the water surface may be skimmed from the forebay into the sluiceway, passing the fish to the tailrace. Overall, sluiceway discharge is a relatively small proportion of total project discharge ( 2\%). Flow into the sluiceway is dependent on forebay elevation and the number and location of open gates. For example, given a forebay elevation equal to $158 \mathrm{ft}$ (above msl) and six sluice gate operating conditions (MU 1-1, 1-2, 1-3, MU 5-2, and MU 18-1, 18-2), flows over the individual weir gates range from 564 (MU 18-2) to 944 (MU 1-1) cfs, with highest flows at the west end nearest the sluiceway channel outlet, and total flow being 4,309 cfs (data provided by Stephen Schlenker, USACE). 


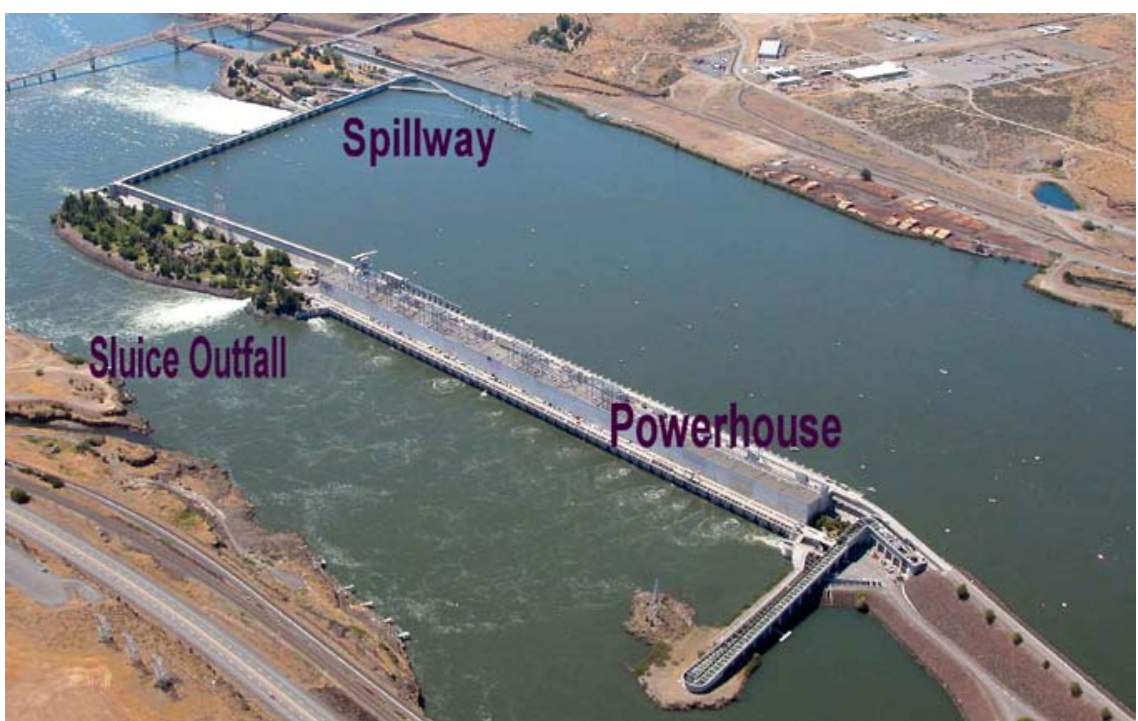

Figure 1.1. Aerial Photograph of The Dalles Dam. Flow is from right to left.

\subsection{Report Contents}

The ensuing sections of this report describe the study methods (Section 2.0), results (Section 3.0), associated discussion and conclusions (Section 4.0), and literature cited (Section 5.0). There are no appendices. 


\subsection{Methods}

The methods section includes descriptions of the general approach, fixed-location hydroacoustics for fish passage, and acoustic imaging for fish behavior.

\subsection{General Approach}

The hydroacoustic and acoustic imaging evaluation of overwintering summer steelhead fallback and steelhead kelt downstream passage at TDA in 2008/2009 was divided into two study periods; late fall/early winter for steelhead fallback (November 1 to December 15; 45 days) and early spring for steelhead kelt passage (March 1 to April 9; 40 days). We obtained fish passage data using fixed-location hydroacoustics and fish behavior data using acoustic imaging.

\subsection{Fixed-Location Hydroacoustics}

The fixed-location hydroacoustic technique was used to accomplish the objective of this study. This technique, conceived by Carlson et al. (1981) for single-beam acoustic systems, is described by Thorne and Johnson (1993). In addition to single-beam technology, split-beam technology is now an important element of fixed-location hydroacoustics. The split-beam technique is explained by MacLennan and Simmonds (1992). The methods used in this study were similar to those used in the 2004 and 2005 hydroacoustic studies at TDA (Johnson et al. 2005 and 2006).

The general approach was to deploy a combination of single-beam and split-beam transducers to sample fish, and apply the acoustic screen model (Johnson 2000) to estimate fish passage rates and distributions. Split-beam transducers provided data to determine weighting factors, assess assumptions of the model, and determine the magnitude of any biases. Split-beam transducer deployments at each type of passage route were used to estimate the average backscattering cross section of fish for detectability modeling and the direction of fish travel through sampling volumes to assess the assumptions of the acoustic screen model. Single- and split-beam transducers were deployed to sample fish passage at the sluiceway and turbines. Transducer sampling volumes were positioned to minimize ambiguity in ultimate fish passage routes and the potential for multiple detections of the same fish.

\subsubsection{Hydroacoustic Systems}

Data collection involved three Precision Acoustic Systems (PAS) single-beam hydroacoustic systems and six PAS split-beam systems. All systems operated at $420 \mathrm{kHz}$. The data-collection systems consisted of either Harp-1B (Single-Beam) or Harp-SB (Split-Beam) Data Acquisition/Signal Processing Software installed on a personal computer controlling a PAS-103 Multi-Mode Scientific Sounder. The PAS-103 sounders controlled transducers deployed in main turbine units and sluice entrances. A total of 34 transducers (18 single-beam and 16 split-beam) were deployed at the powerhouse and sluiceway (Table 2.1). During data collection, all systems used a voltage output threshold range of -26 to $-56 \mathrm{~dB}$ re: $1 \mu \mathrm{Pa}$ at $1 \mathrm{~m}$. 
Table 2.1. Sample Locations and Spatial Sampling Intensity at The Dalles Dam in 2008/2009

\begin{tabular}{lcccl}
\hline \multicolumn{1}{c}{ Unit } & $\begin{array}{c}\text { Intensity } \\
\text { by Unit }\end{array}$ & $\begin{array}{c}\text { Intensity by } \\
\text { Intake }\end{array}$ & $\begin{array}{c}\text { Number of } \\
\text { Transducers }\end{array}$ & \multicolumn{1}{c}{ Sample Locations } \\
\hline Main Units 1-22 & 22 of 22 & 1 of 3 & 22 & $\begin{array}{l}\text { MU 1-1, 2-3, 3-1, 4-3, 5-1, 6-1, 7-2, 8-2, 9-2, 10-1, } \\
\text { 11-3, 12-2, 13-3, 14-2, 15-3, 16-3, 17-2, 18-2, 19-1, } \\
\end{array}$ \\
& & & & $\begin{array}{l}20-2,21-2,22-1 \\
\text { Sluice entrances 1-1, 1-2, 1-3 }\end{array}$ \\
Sluice 1 & 1 of 1 & 3 of 3 & 6 & $\begin{array}{l}\text { Sluice entrance 5-2 } \\
\text { Sluice } 5\end{array}$ \\
Sluice 18 & 1 of 1 & 1 of 3 & 2 & Sluice entrances 18-1, 18-2 \\
\hline
\end{tabular}

\subsubsection{Transducer Locations and Orientations}

Single-beam transducers $\left(6^{\circ}\right)$ were installed at all turbine unit sampling locations, except for MU 2, MU 5, MU 16, and MU 18, each of which had a $6^{\circ}$ split-beam transducer (Figure 2.1). The intakes sampled at a given turbine unit were randomly chosen. At all turbine intake sampling locations, divers installed transducers on the bottom of the second to the bottom trash rack at elevation $75 \mathrm{ft}$ and aimed the transducers downstream and upward toward the intake ceiling at a $23^{\circ}$ angle to the plane of the trash rack (Figure 2.2). The transducer mounts were designed to fit between the vertical bars of the trash rack. This design allowed divers to secure the mount to the trash rack of each intake from the forebay. A diver took a transducer/mount/cable assembly to the bottom of the trash rack located just above the deepest installed rack (Figure 2.2). The diver then installed the mount between two vertical bars of the trash rack at elevation $75 \mathrm{ft}$ and secured the mount to the trash rack with "J" bolts.

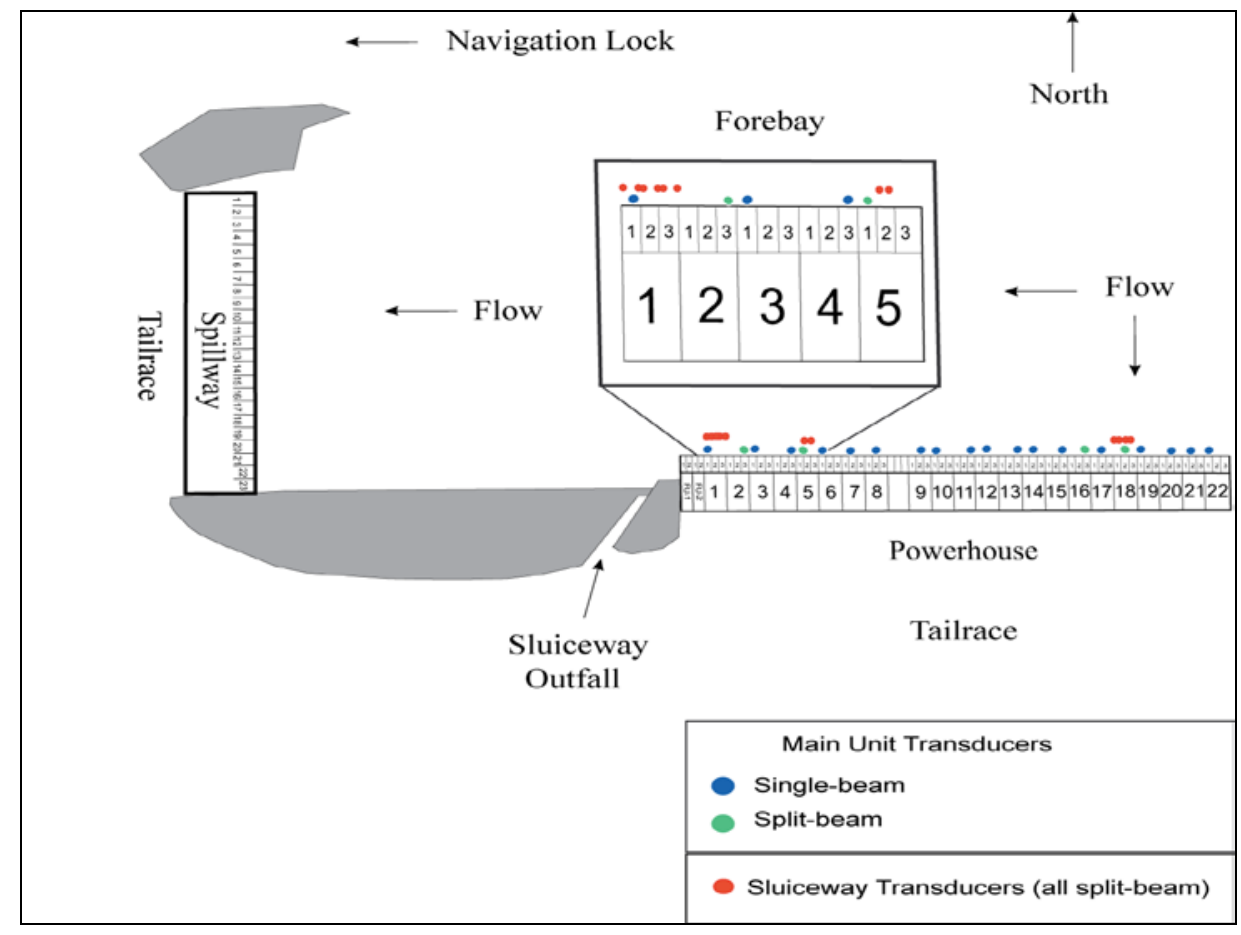

Figure 2.1. Plan View of The Dalles Dam Showing Transducer Locations 


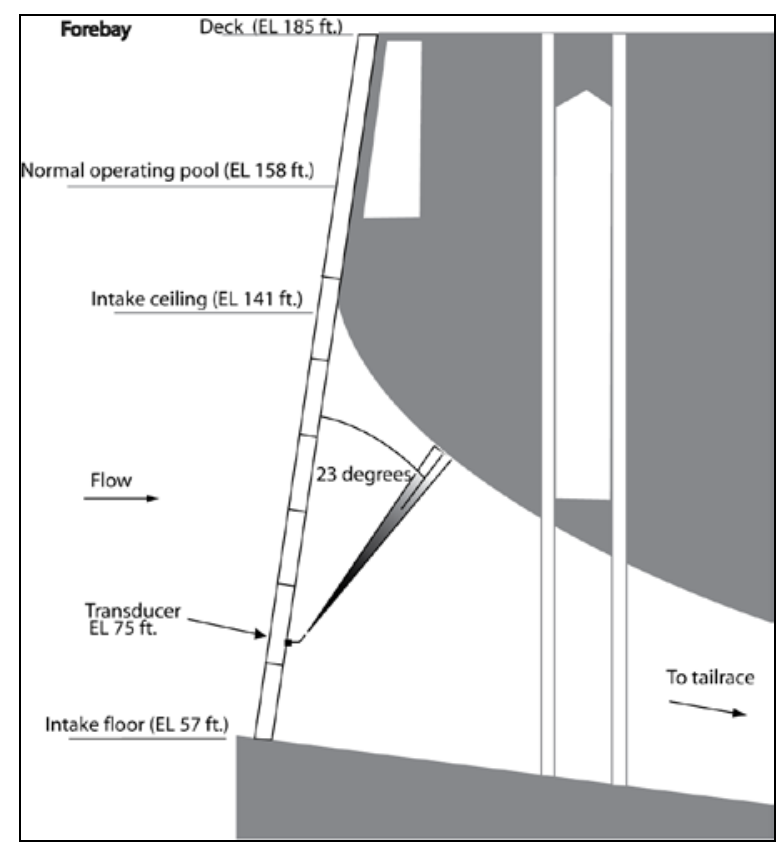

Figure 2.2. Cross-Sectional View of a Main Unit Intake Transducer Deployment

Sluiceway transducers ( $6^{\circ}$ split-beam) were installed at each of the three sluice entrances of MU 1 , one sluice entrance at MU 5 (5-2), and two sluice entrances at MU 18 (18-1, 18-2) at elevation $153 \mathrm{ft}$. Transducers were attached to trolley mounts, which were then affixed to steel I-beams attached to the front of pier noses and lowered into the water (Figure 2.3). Each sluice entrance was monitored by a pair of transducers aimed horizontally and back at a $60^{\circ}$ angle to the plane of the sill across the sluice entrance with a $6^{\circ}$ up-looking angle (Figures 2.4, 2.5, and 2.6).

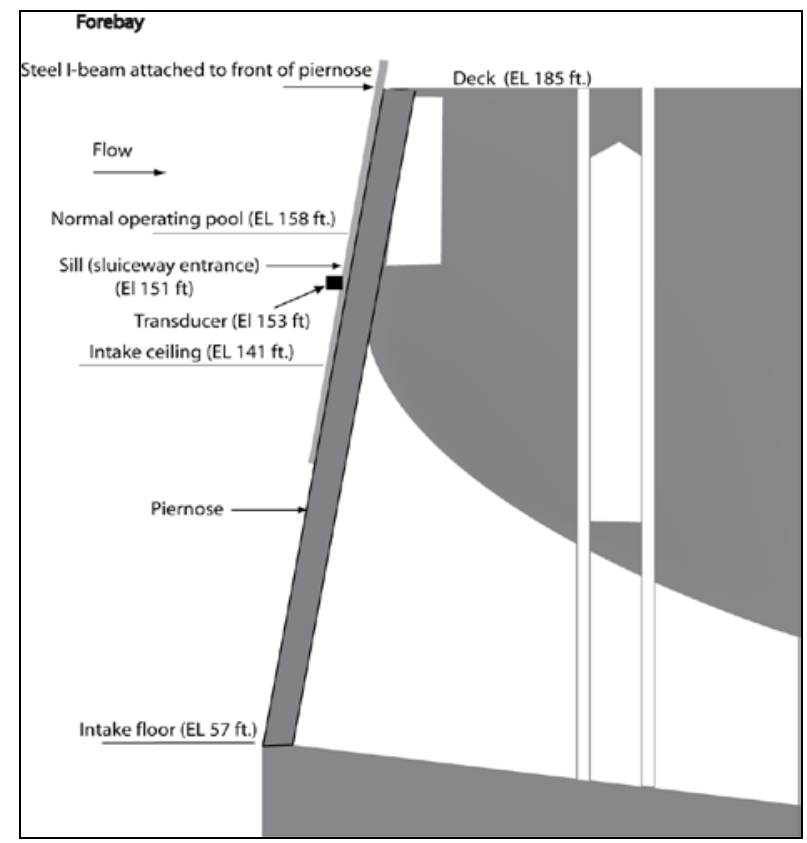

Figure 2.3. Deployment for a Side-Looking Sluiceway Transducer Mounted on a Steel I-Beam Attached to the Front of a Pier Nose 


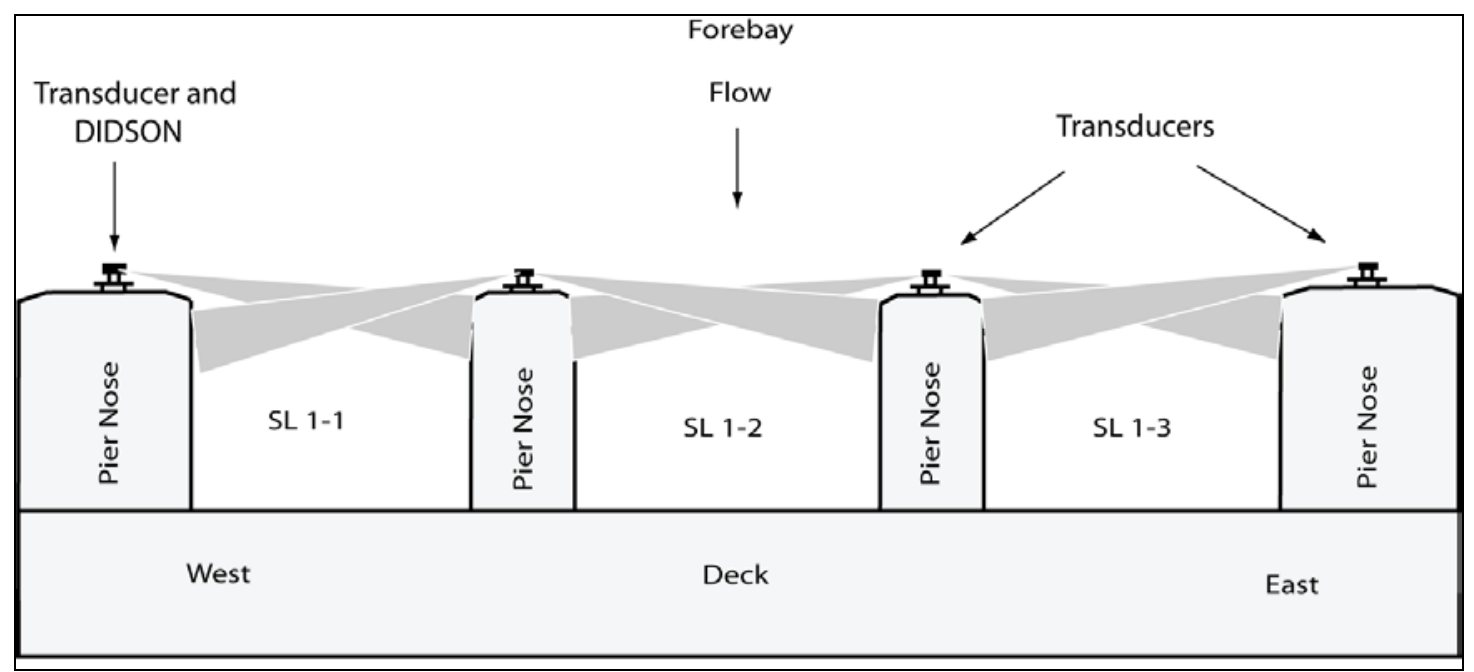

Figure 2.4. Top View of Transducer Deployment for Sluice 1

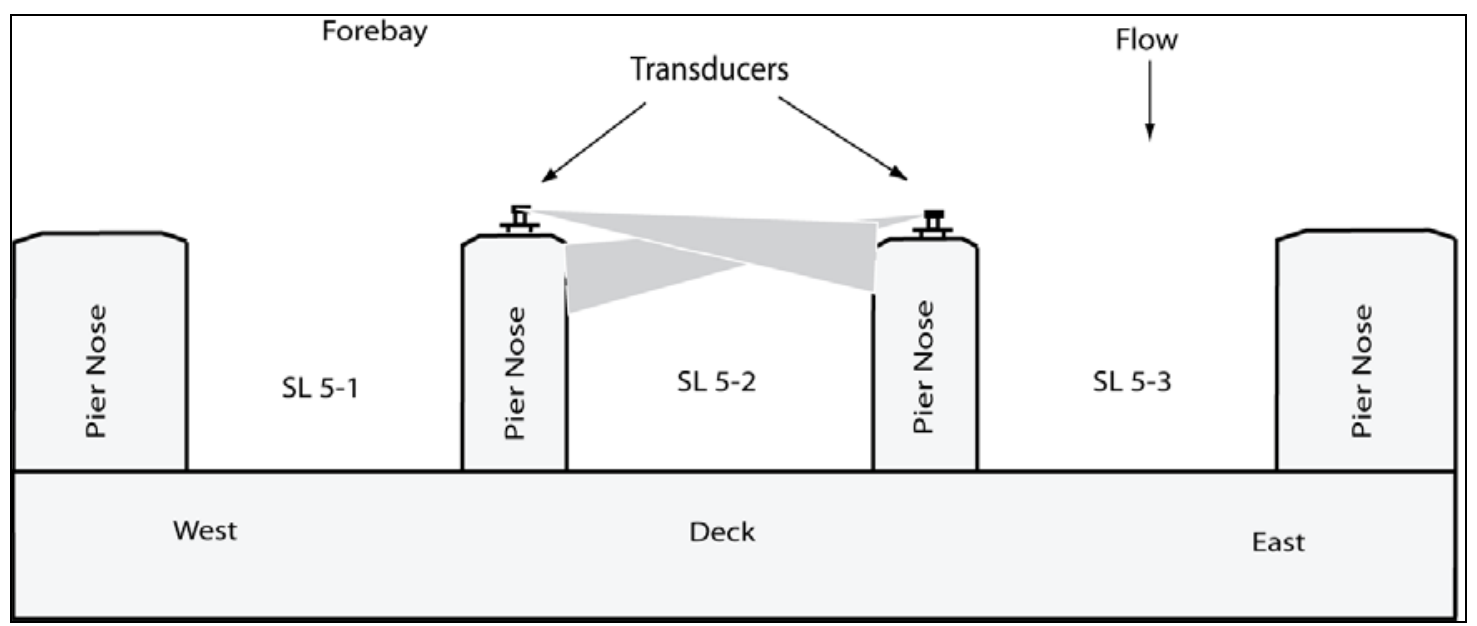

Figure 2.5. Top View of Transducer Deployment for Sluice 5

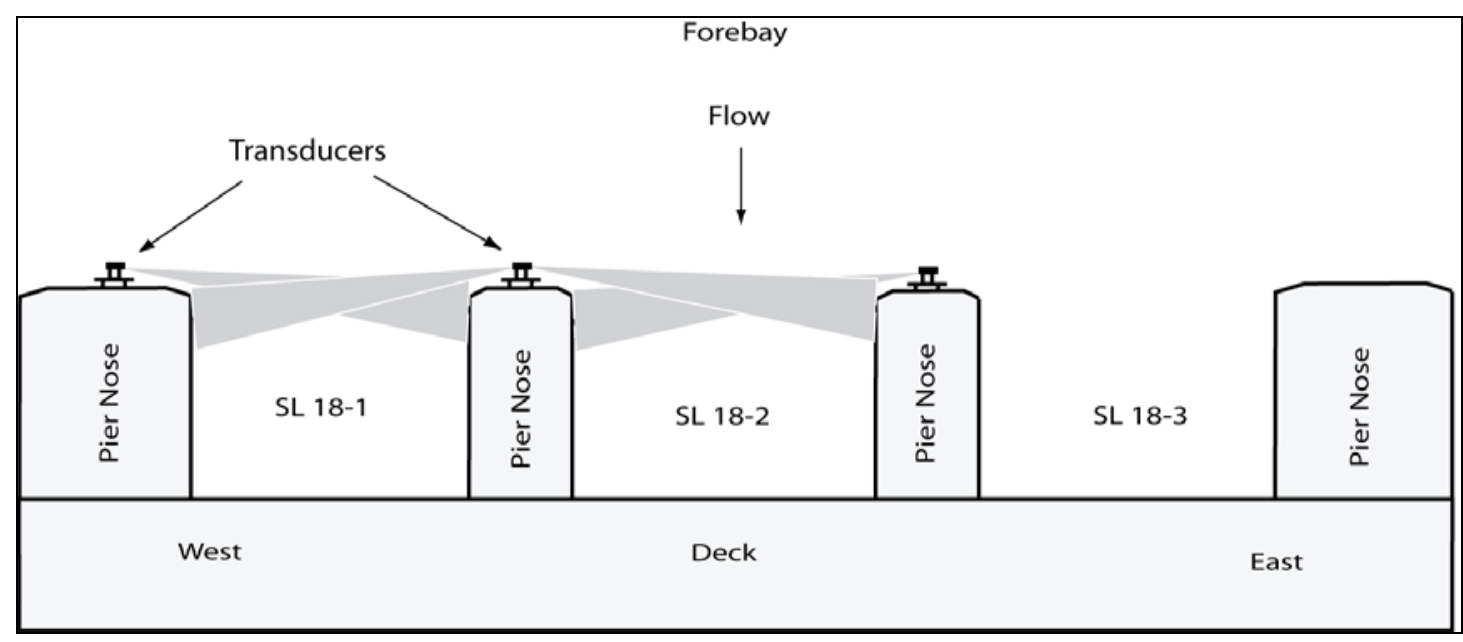

Figure 2.6. Top View of Transducer Deployment for Sluice 18 


\subsubsection{Sampling Design}

Echo sounder transmission rates were 15 pps (pings per second) at the turbine intakes and 33 pps at the sluiceway. Systematic samples, i.e., same order among sampling locations each hour, were collected at 1-min intervals $24 \mathrm{~h} / \mathrm{d}$. Each location was sampled 10, 15, 20, or 30 times per hour depending on the number of transducers connected to the echo sounder.

\subsubsection{Data Processing and Analysis}

After the acoustic echo data were collected and archived, they were processed to extract fish tracks. At this stage in the analysis, we were careful to set the tracking parameters to include all fish at the expense of including spurious tracks. Next, to separate acceptable from unacceptable tracks, we filtered using fish tracks characteristics such as mean target strength, slope, speed, and pulse width. Subsamples of the data were manually checked to assure that valid fish tracks remained after filtering. Data processing and reduction methods were similar to those used by Johnson et al. (2005). Mean target strength as an indicator of fish size was used to distinguish relatively large adult steelhead fallback and kelt passage from smaller targets such as juvenile shad. The maximum target strength was set at - $26 \mathrm{~dB}$ re: $1 \mu \mathrm{Pa}$ at $1 \mathrm{~m}$ during data collection. In retrospect, this threshold may have excluded some of the larger steelhead (Nealson and Gregory 2000). During data processing, we filtered for large fish using mean target strengths (Table 2.2) based on the expected sizes of the smallest fish of interest of about $30 \mathrm{~cm}$ (personal communication from R. Wertheimer, USACE) and the relationship between fish length and target strength for adult salmon in side aspect described by Burwen and Fleischman (1998). The 3-dB difference between sluice and turbine target strengths accounted for the side and ventral aspects, respectively, of the transducers relative to the fish.

Table 2.2. Mean Target Strength Filters

\begin{tabular}{lcc}
\hline & $\begin{array}{c}\text { Late Fall 2008 } \\
\text { Steelhead Fallback }\end{array}$ & $\begin{array}{c}\text { Early Spring 2009 } \\
\text { Steelhead Passage }\end{array}$ \\
\hline Sluice & $-29 \mathrm{~dB}$ & $-31 \mathrm{~dB}$ \\
Turbine & $-32 \mathrm{~dB}$ & $-34 \mathrm{~dB}$ \\
\hline
\end{tabular}

The process used to estimate passage rates from filtered tracked fish involved spatial and temporal extrapolations. Briefly, each fish track that survived the filtering process was weighted spatially to account for the sample width of the acoustic beam at the target's mid-range relative to the width of the depth bin it sampled; i.e., fish passage at unsampled portions of a passage route was estimated by extrapolating from the sampled areas. Turbine estimates were multiplied by three because one of three intakes at a given unit was sampled. The sum of these weighted fish was then extrapolated temporally by the hourly sampling fraction (60/total hourly sample time per location).

The hourly passage rate data for each transducer were used to estimate various performance metrics. Equations for each estimator follow. Let $x_{i j k y}$ be the expanded fish passage count in the $i^{\text {th }}$ transducer ( $i=1, \ldots, x)$ during the $j^{\text {th }}$ hour $(j=1, \ldots, 24)$ of the $k^{\text {th }}$ day $\left(k=1, \ldots, d_{y}\right)$ during $y^{\text {th }}$ study period, where $d_{y}$ is the number of study-days in the $y^{\text {th }}$ study period (late fall 2008 or early spring 2009). 
Total adult steelhead fallback (or kelt passage) for the $y^{\text {th }}$ study period was estimated by the formula

$$
\widehat{T P_{y}}=\sum_{i=1}^{6} \sum_{j=1}^{24} \sum_{k=}^{d_{y}} x_{i j k y}
$$

Daily adult steelhead fallback (or kelt passage) for the $k^{\text {th }}$ day in the $y^{\text {th }}$ study period for analysis of run timing was estimated by the formula

$$
\widehat{D P_{k y}}=\sum_{i=1}^{6} \sum_{j=1}^{24} x_{i j k y}
$$

Hourly adult steelhead fallback (or kelt passage) for the $j^{\text {th }}$ hour in the $y^{\text {th }}$ study period for analysis of diel distribution was estimated by the formula

$$
\widehat{H P_{j y}}=\sum_{i=1}^{6} \sum_{k=1}^{d_{y}} X_{i j k y}
$$

Johnson et al. (2005) describe methods to estimate variances for the passage rate estimates. The variances associated with each passage rate estimate were likely underestimated because between-intake variability in passage within a given turbine unit could not be accounted for because of sampling limitations. Ninety-five percent confidence intervals (CIs) for total and daily passage rates were calculated as follows:

$$
C I= \pm 1.96 * \sqrt{\text { Variance }}
$$

\subsection{Acoustic Imaging}

To determine fish movements at the sluiceway, a Dual Frequency Identification Sonar (DIDSON) was deployed at the sluice entrance of MU 1-1. The DIDSON bridges the gap between conventional scientific fisheries sonar, which can detect acoustic targets at long ranges but cannot record the shapes of targets, and optical systems, which can record images of fish but have limited range at low light levels or when turbidity is high. The DIDSON has high resolution and a fast frame rate enabling it to substitute for optical systems in turbid or dark water. This device was successfully applied at the TDA sluiceway in previous research on juvenile salmonids passage (Johnson et al. 2005, 2006). Figure 2.7 shows an example of an image of adult salmonid and juvenile shad observed using the DIDSON in 2008. 


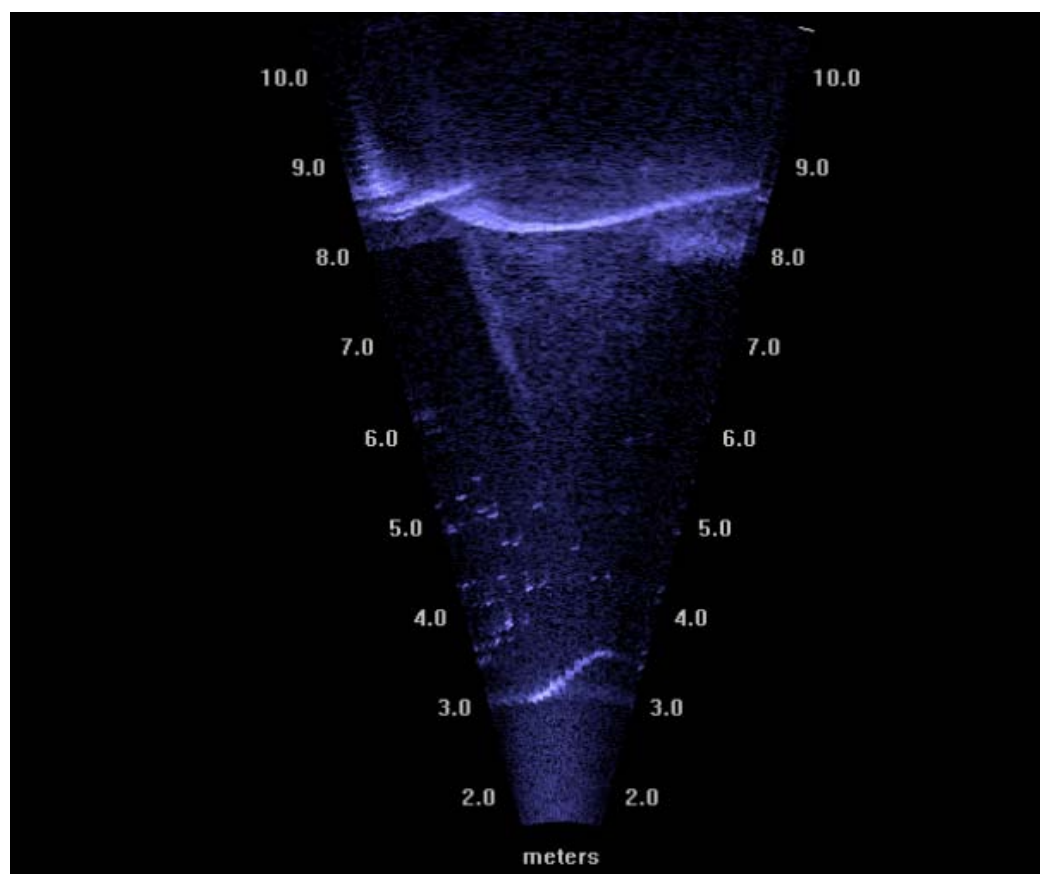

Figure 2.7. Screen from the DIDSON Display. The image shows one adult fish (foreground, $\sim 3-\mathrm{m}$ range) and juvenile fish ( 3.5- to 5-m range) entering TDA sluice entrance 1-1 in November 2008. The sluice entrance is to the right in the image. The adult fish is oriented tail-first into the sluice.

\subsubsection{Sampling Locations}

The DIDSON was used to sample fish movement and behavior at sluice entrances 1-1 and 1-2. DIDSON data were collected $24 \mathrm{~h} / \mathrm{d}$ during both study periods. The DIDSON was mounted to a trolley and deployed on a 4-in.-wide steel I-beam attached to the front of the westernmost pier of main unit 1, at elevation $154 \mathrm{ft}$ (Figure 2.8). The instrument was aimed across the front of the sluice entrances 1-1 and 1-2 (Figure 2.9). The DIDSON was used in the low-frequency mode and the frame rate was 6-7 frames/s.

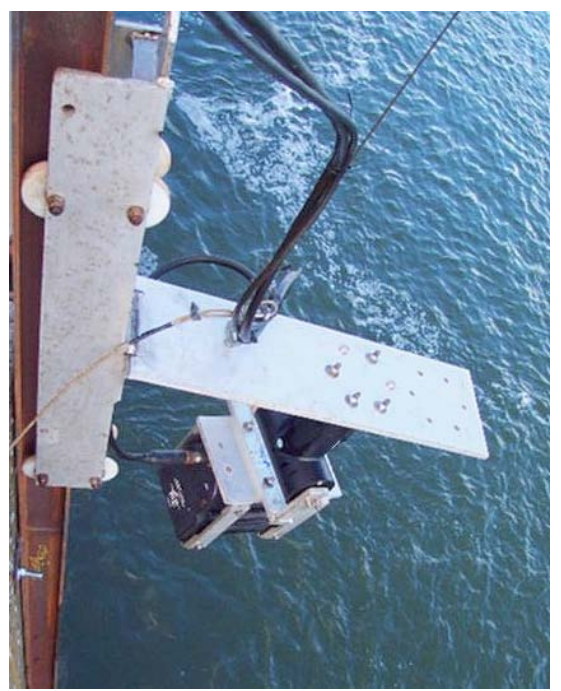

Figure 2.8. DIDSON

Mounted to Trolley and Deployed on an I-Beam on the Front of the Pier 


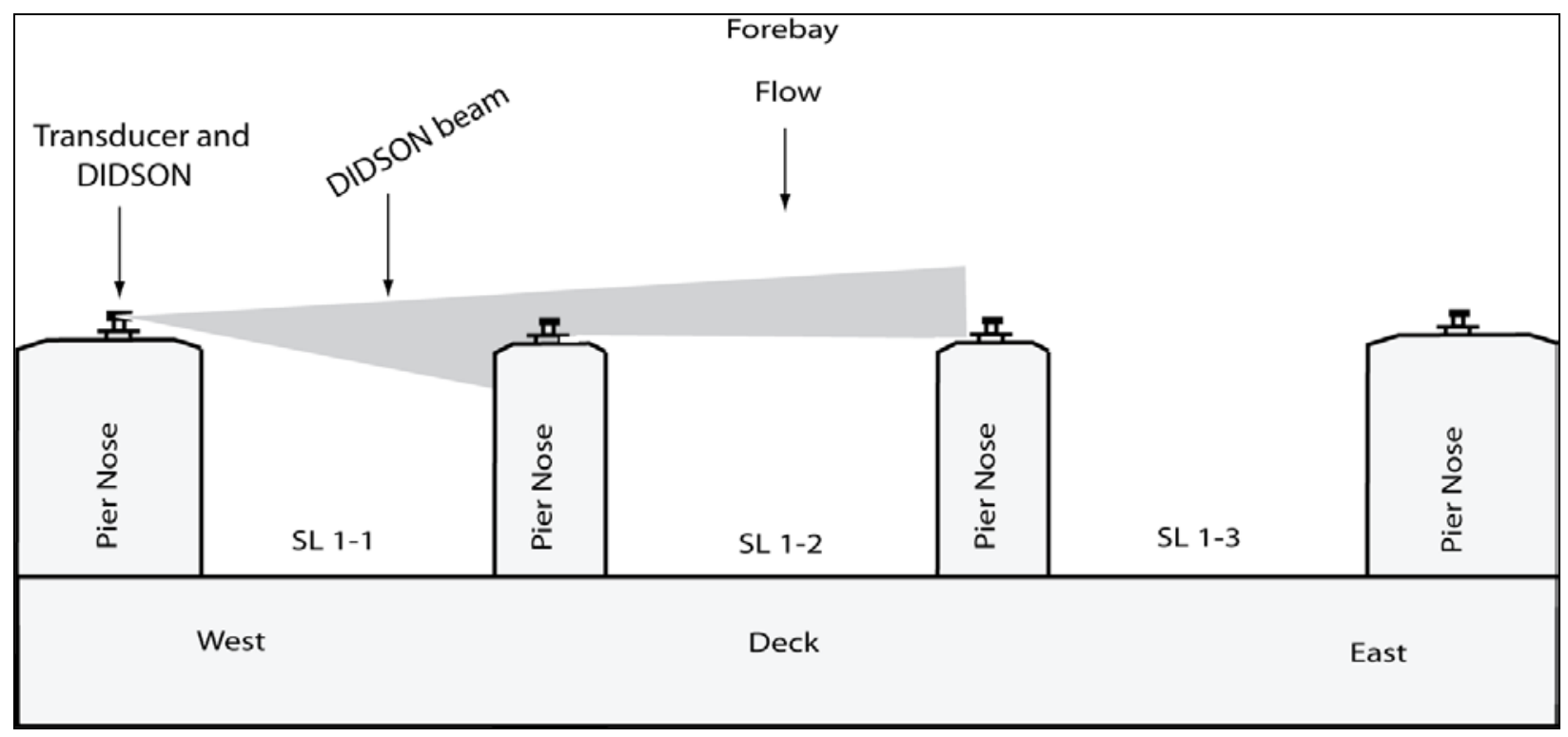

Figure 2.9. Top View Showing the DIDSON Sampling Location at Sluice (SL) 1. The DIDSON beam was aimed to sample across SL 1-1 and 1-2.

\subsubsection{Data Processing}

Observational data for fish behavior at the sluiceway were obtained from a subset of the DIDSON data. Because of the large amount of data collected (video files), we randomly selected 4 hours (1 hour from each 6-hour block of a 24-hour day) for each day of the study and reviewed each hour in the subset for fish behavior. We recorded behavior categories such as fish entering the sluiceway, swimming away from the sluiceway into the forebay, and orientation and milling patterns in front of the sluiceway.

As a result of observations made during processing of the acoustic images, we performed a cursory passage analysis on the fixed-location hydroacoustics dataset by filtering for mean target strengths between -36 and $-56 \mathrm{~dB}$. We used these data to examine run timing curves for juvenile fish during both study periods. 


\subsection{Results}

The results from the study are organized into three main sections: environmental conditions, fish passage evaluation, and fish behavior observations.

\subsection{Environmental Conditions}

Daily outflow at TDA ranged from 70 to $155 \mathrm{kcfs}$ during the fall/winter study period (November 1December 15), with a mean daily outflow of 117 kcfs (Figure 3.1). For the spring study period (March 1April 9), daily outflow ranged from 100 to 212 kcfs, with a mean daily outflow of 133 kcfs (Figure 3.1). Spill commenced on April 10 for juvenile salmonid migration.
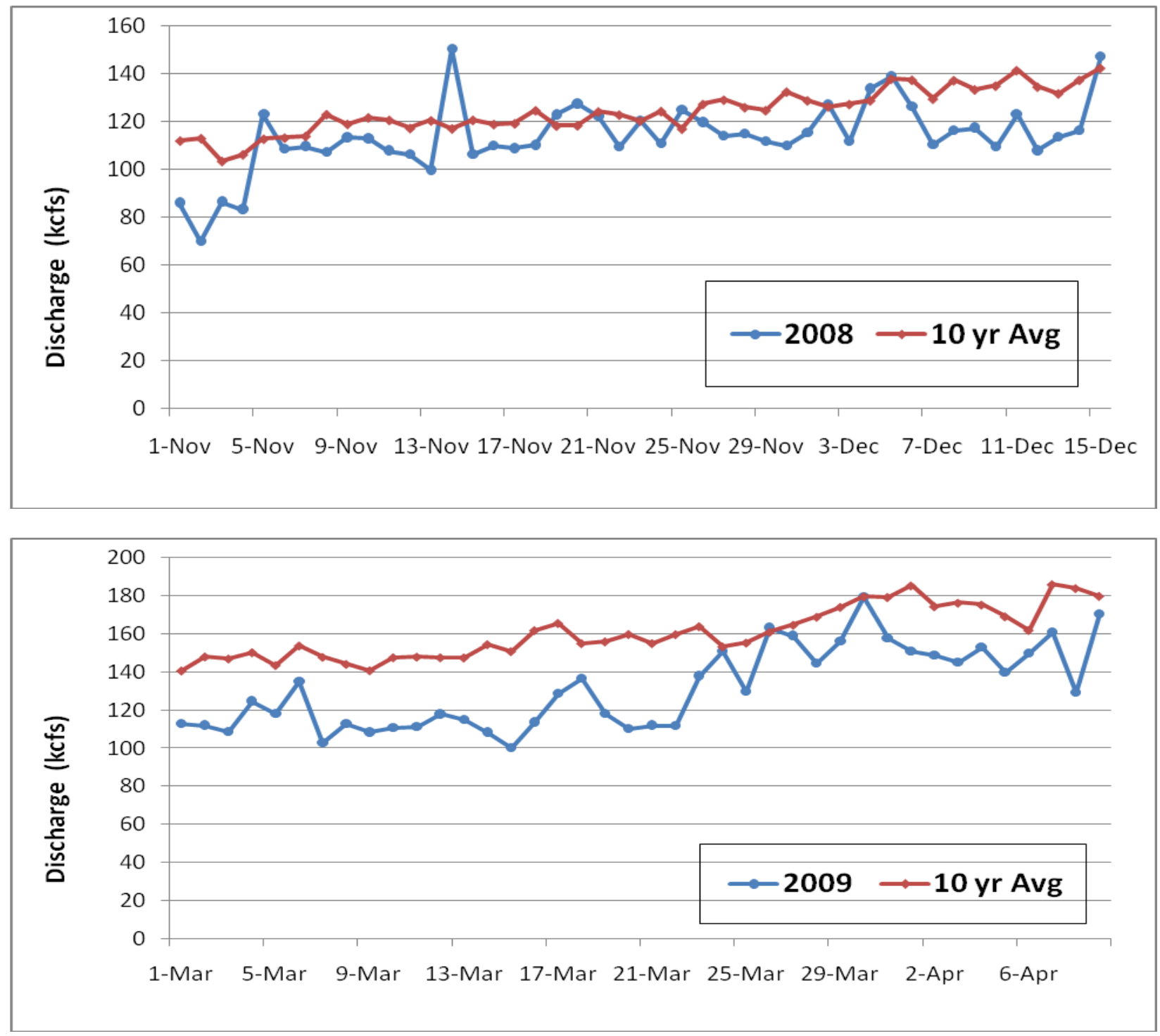

Figure 3.1. Total Outflow and 10-Year Average Outflow (kcfs) at TDA During Fall/Winter 2008 (top) and Early Spring 2009 (bottom). Data were obtained from DART

(http://www.cbr.washington.edu/dart/dart.html), accessed on July 1, 2009. 
During the fall/winter study period (November 1-December 15), forebay elevation at TDA ranged from 158 to $159.4 \mathrm{ft}$ above msl, with an average elevation of $158.8 \mathrm{ft}$ above msl (Figure 3.2). Sluiceway discharge ranged from 4.31 to $4.86 \mathrm{kcfs}$, with an average discharge of $4.63 \mathrm{kcfs}$ (Figure 3.2).

For the early spring study period (March 1-April 9), forebay elevation at TDA ranged from 158.2 to $159.6 \mathrm{ft}$ above msl, with an average elevation of $159 \mathrm{ft}$ above msl (Figure 3.2). Sluiceway discharge ranged from 4.39 to $4.94 \mathrm{kcfs}$, with an average discharge of $4.72 \mathrm{kcfs}$ (Figure 3.2).
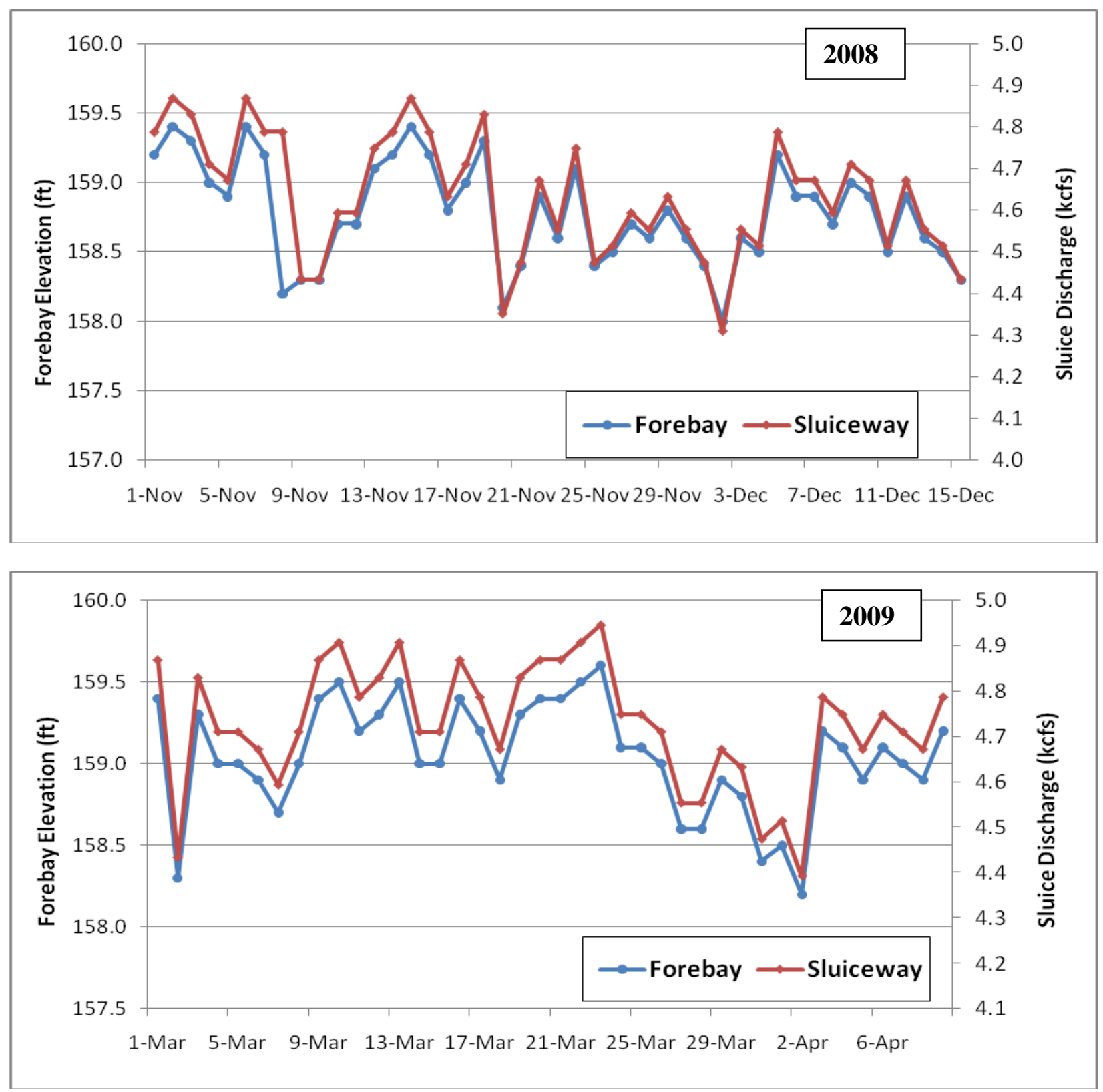

Figure 3.2. Forebay Elevation (ft above msl) and Total Sluiceway Discharge (kcfs) at TDA During Fall/Winter 2008 (top) and Early Spring 2009 (bottom). Forebay data were obtained from DART (http://www.cbr.washington.edu/dart/dart.html), accessed on July 1, 2009. Sluiceway discharge data were obtained from Stephen Schlenker, USACE. 


\subsection{Fish Passage Evaluation}

Fish passage results are organized into two main sections: overwintering summer steelhead fallback in late fall/early winter and overwintering summer steelhead and early out-migrating steelhead kelt downstream passage in early spring. Under each of these topics, we present data on passage rates, run timing, horizontal distribution, and diel distribution.

\subsubsection{Overwintering Summer Steelhead Fallback}

\subsubsection{Passage Rates and Run Timing}

During the 45-day study period November 1 to December 15, 2008, a total of 1,790 \pm 250 (95\% CI) summer steelhead passed through the powerhouse intakes and operating sluice entrances. The mean number of fish passing (falling back) the dam on a daily basis was 40. At the sluiceway, 1,704 targets passed (95\% of the total dam passage) and 86 passed through the powerhouse intake units. Run timing peaked in late November (Figure 3.3). Fallback occurred (10-25 fish/d) during the first and last days of the study period.

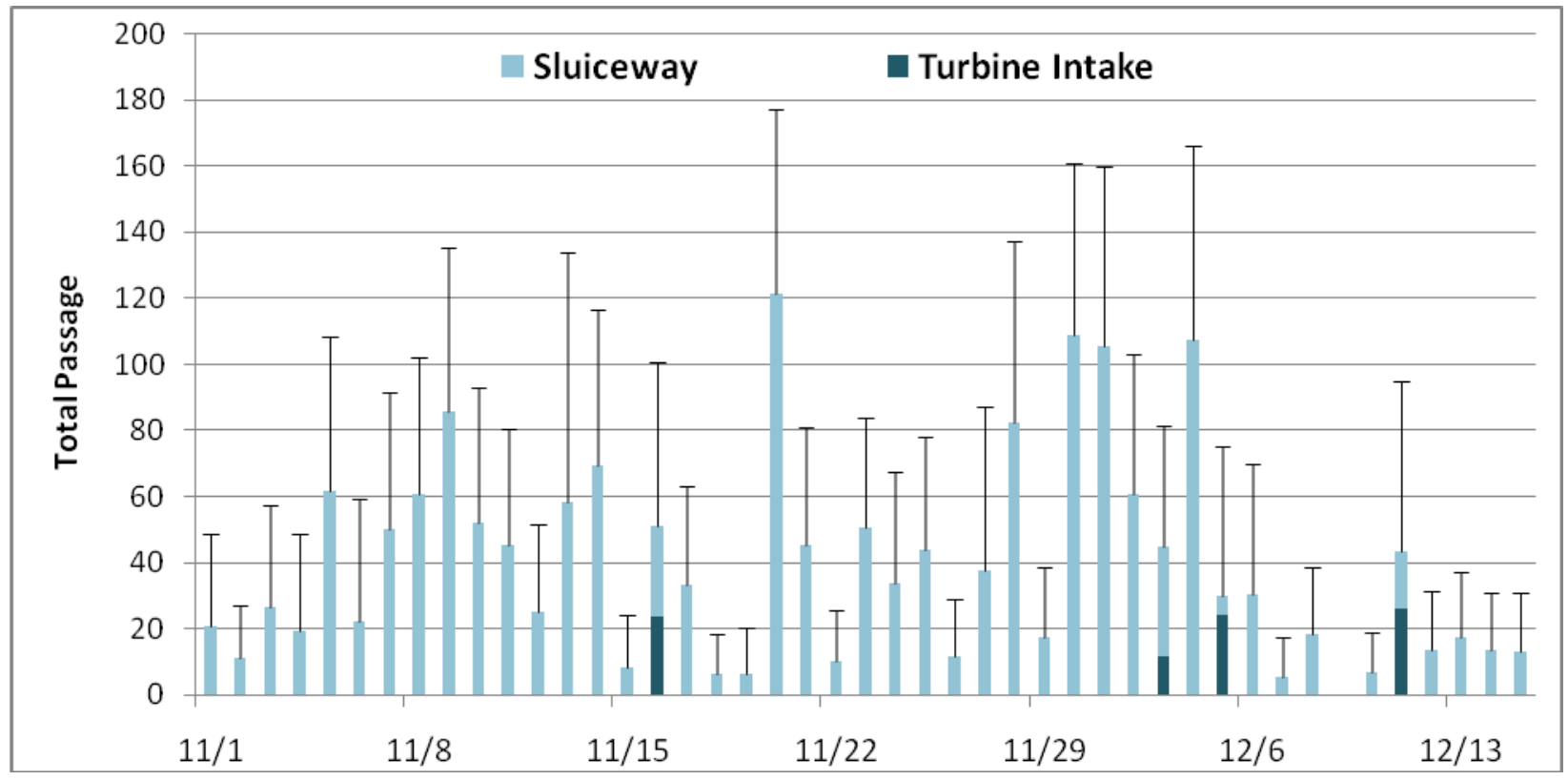

Figure 3.3. Total Number of Overwintering Summer Steelhead Targets Passing Daily at Each Route of the Powerhouse and Sluiceway from November 1-December 15, 2008 (95\% CI)

\subsubsection{Horizontal Distribution}

Fallback of overwintering steelhead was highest at Sluice 1 (1,453 targets). Sluice 18 had the second highest number of fish passing (211) and a small number passed through Sluice 5 (40 fish) and powerhouse intake units 7, 8, and 18 (23, 51, and 12 fish, respectively) (Figure 3.4). For individual sluice entrances, sluice entrance 1-3 passed the highest number of fish (1,192 targets), followed by sluice entrance 1-2 (195) and sluice entrance 18-2 (122). Fewer than one hundred targets passed through sluice entrances 1-1, 5-2, and 18-1 (Figure 3.5). 


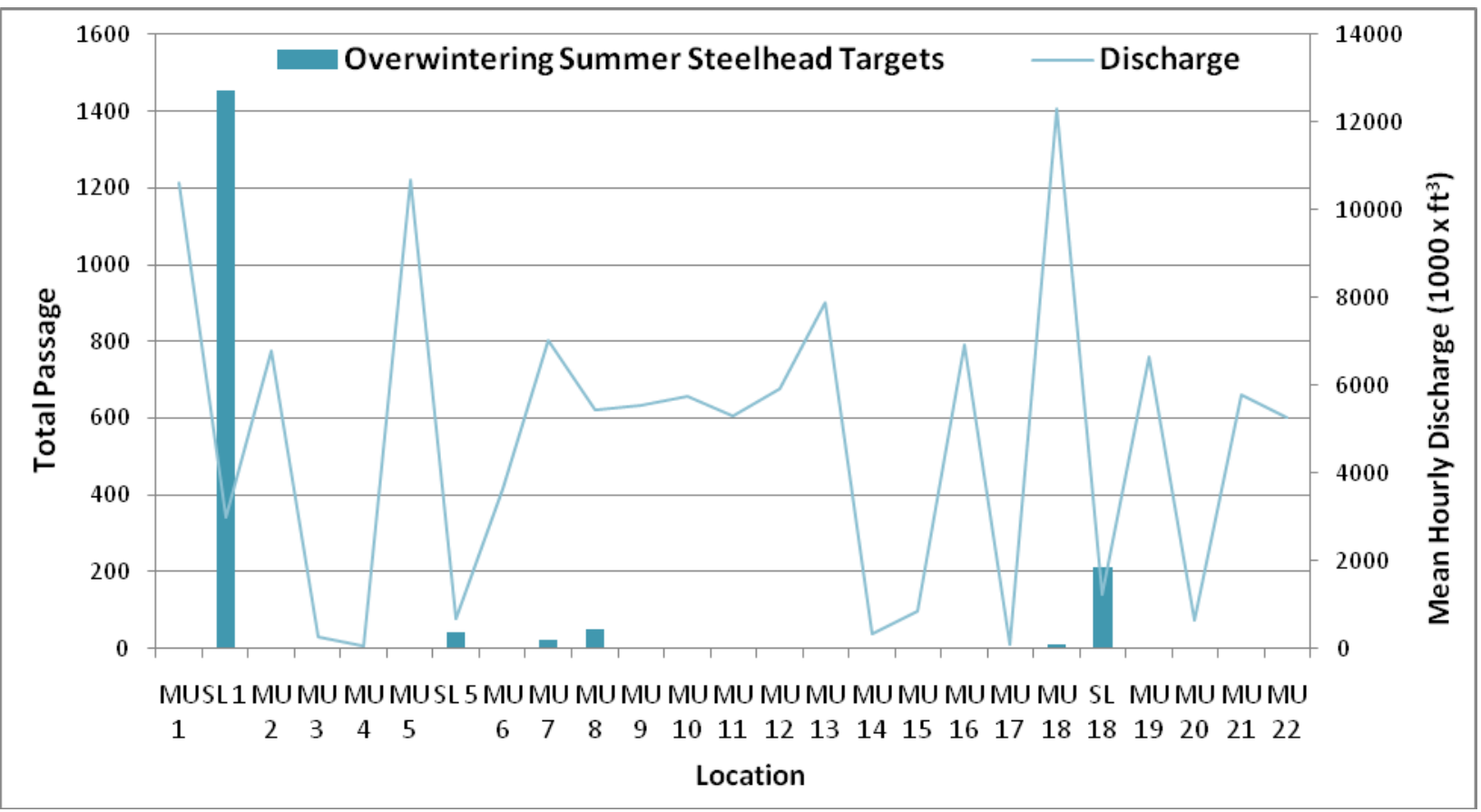

Figure 3.4. Horizontal Distribution of Total Passage Overwintering Summer Steelhead Targets at Each Route of the Powerhouse and Sluiceway, with Corresponding Powerhouse Intake Unit and Sluiceway Discharge, from November 1-December 15, 2008 (MU = main unit, SL = sluice)

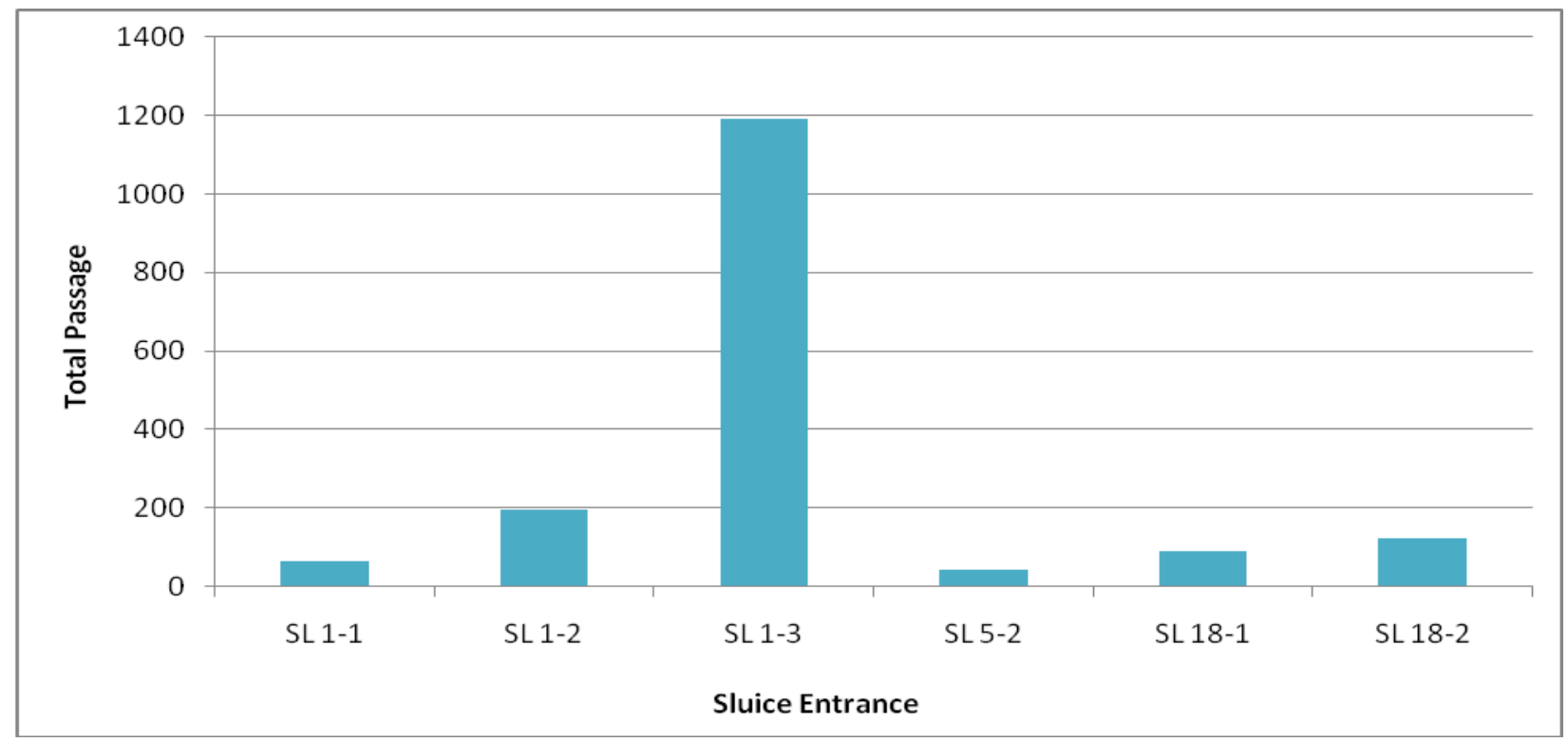

Figure 3.5. Horizontal Distribution of Total Passage of Overwintering Summer Steelhead Targets at Each Route of the Sluiceway from November 1-December 15, 2008 (SL = sluice entrance) 


\subsubsection{Diel Distribution}

Diel distribution of overwintering steelhead fallback was highly variable and had no consistent pattern (Figure 3.6). Higher hourly estimates were often within 1 to 2 hours of below average estimates.

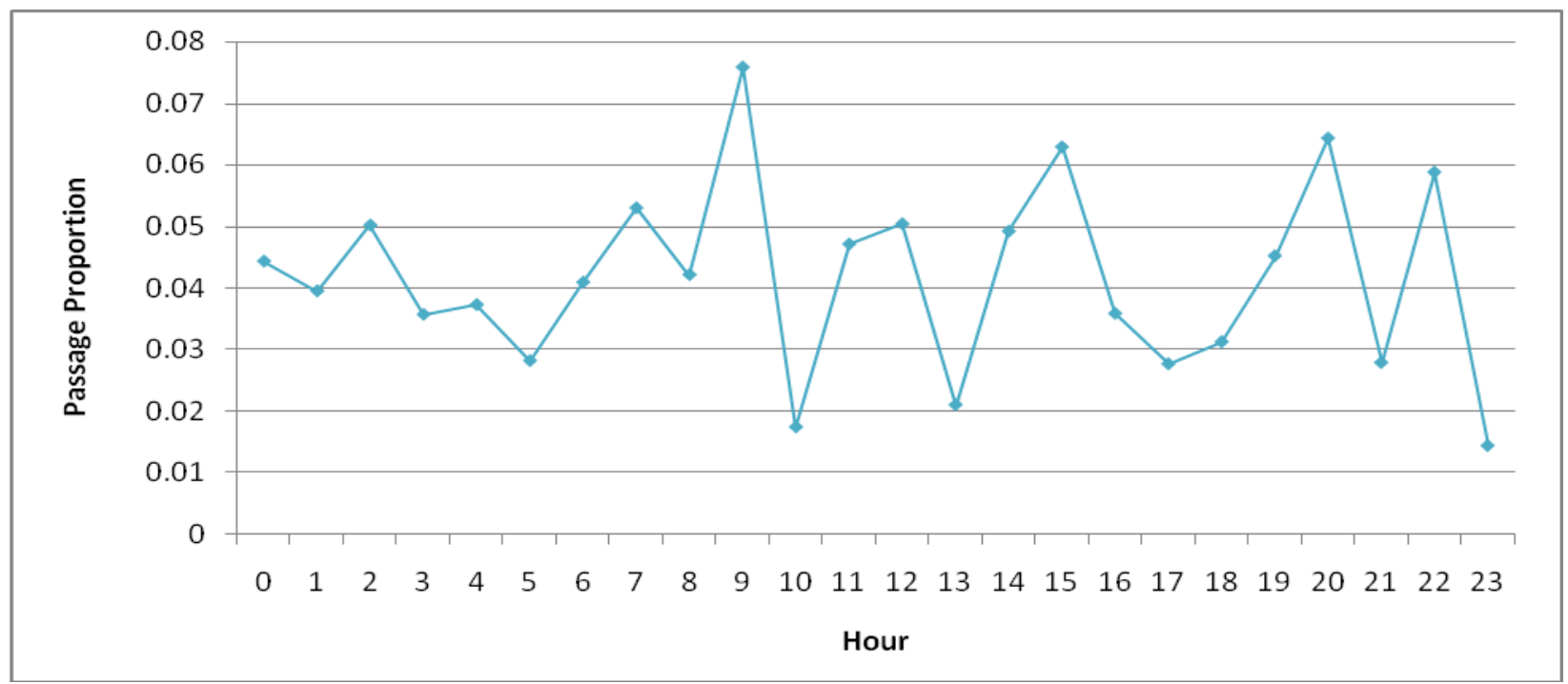

Figure 3.6. Diel Distribution of Overwintering Summer Steelhead Targets from November 1December 15, 2008. Data are the hourly proportions of total passage.

\subsubsection{Overwintering Summer Steelhead and Early Out-Migrating Kelt Downstream Passage}

\subsubsection{Passage Rates and Run Timing}

During the 40-day study period March 1-April 9, 2009, a total of 1,766 \pm 277 (95\% CI) steelhead adult-sized targets passed through the powerhouse intakes and operating sluices. An average number of 44 targets passed the dam on a daily basis. A total of 1,673 targets passed through the sluiceway (95\% of the total) and 93 passed through the powerhouse intake units. Run timing peaked in late March (Figure 3.7). However, relatively large numbers of targets passed the dam on March 2 and March 6, 2009.

\subsubsection{Horizontal Distribution}

Total overwintering steelhead and out-migrating kelt passage was highest at Sluice 1 (1,091 targets). Sluice 18 had the second highest number of fish passing (454). One hundred twenty-eight targets passed at Sluice 5 and a small number passed through the powerhouse intake units 8, 21, and 22 (24, 23, and 46 fish, respectively) (Figure 3.8). For individual sluice entrances, sluice entrance 1-3 passed the highest number of fish (785 targets), followed by sluice entrance 18-1 (337) and sluice entrance 1-2 (205). Sluice entrances 5-2 and 18-2 passed 127 and 117 targets, respectively. Sluice entrance 1-1 passed the least amount of fish (101) (Figure 3.9). 


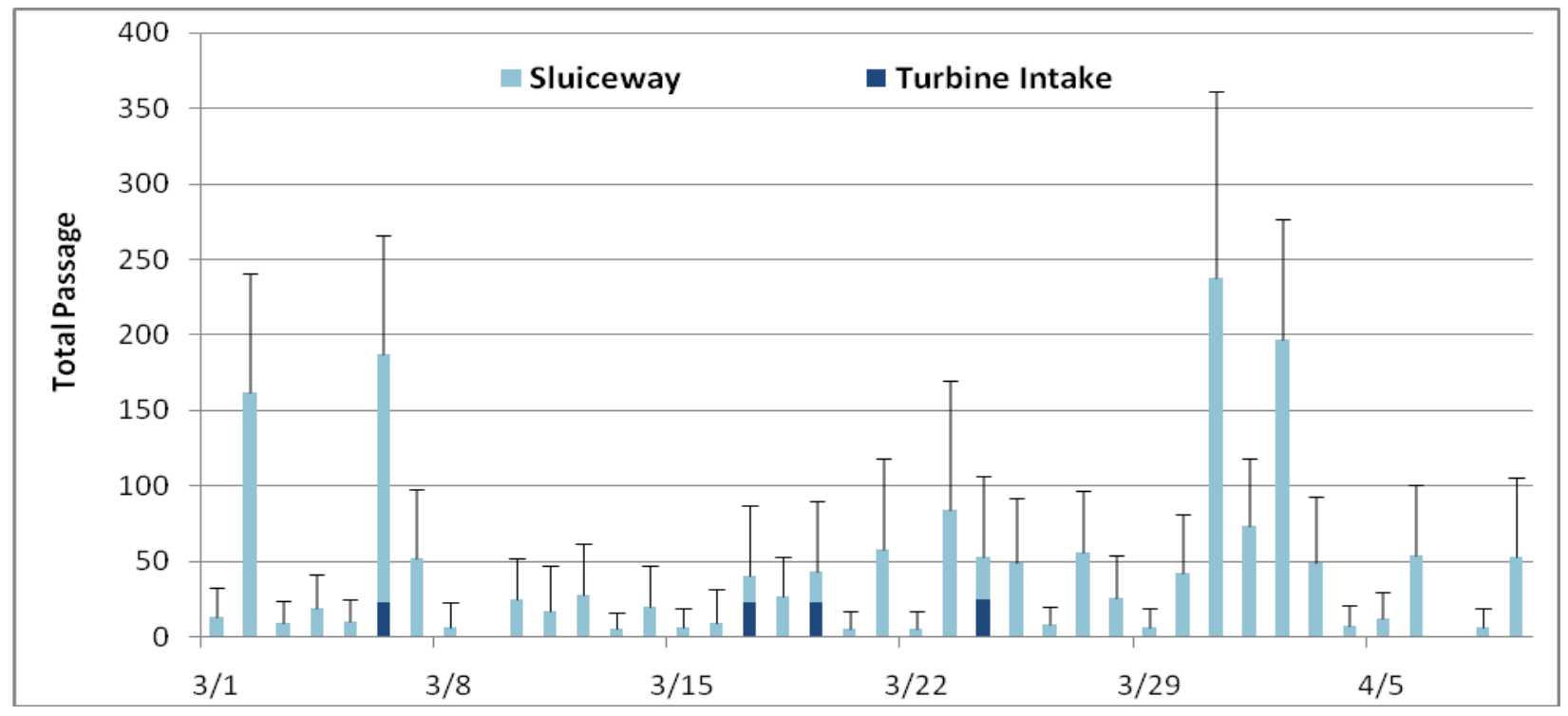

Figure 3.7. Total Number of Overwintering Summer Steelhead and Kelt-Sized Targets Passing Daily at Each Route of the Powerhouse and Sluiceway from March 1-April 9, 2009 (95\% CI)

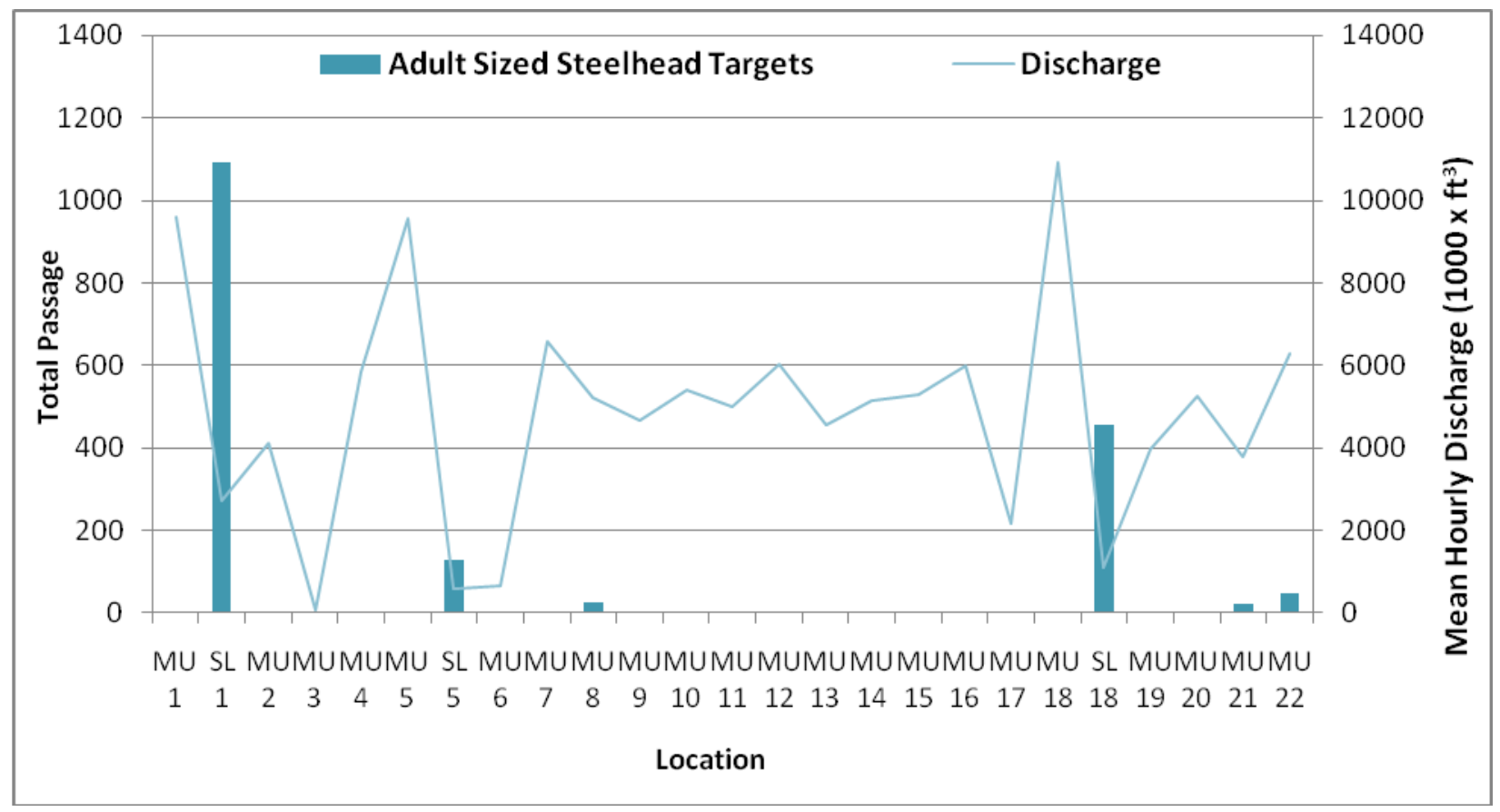

Figure 3.8. Horizontal Distribution of Total Passage of Overwintering Steelhead and Kelt-Sized Targets at Each Route of the Powerhouse and Sluiceway, with Corresponding Powerhouse Intake Unit Discharge, from March 1-April 9, 2009 (MU = main unit, SL = sluice) 


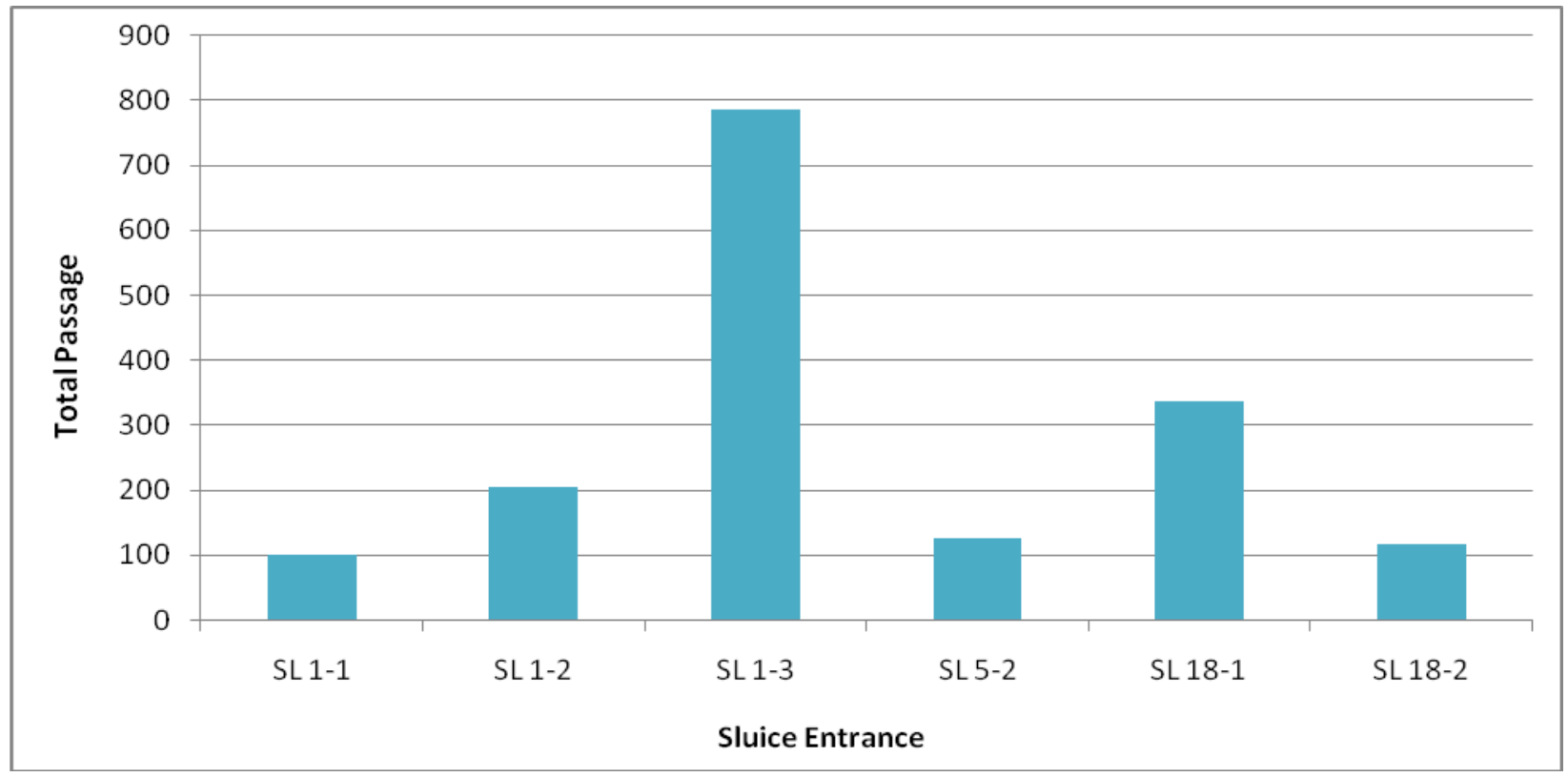

Figure 3.9. Horizontal Distribution of Total Passage of Overwintering Steelhead and Kelt-Sized Targets at Each Route of the Sluiceway from March 1-April 9, 2009 (SL = sluice entrance)

\subsubsection{Diel Distribution}

Passage was high during mid-morning hours and late afternoon/nighttime, except for a dip at $2200 \mathrm{~h}$ (Figure 3.10). Fish passage peaked at $2100 \mathrm{~h}$ and was lowest at $0500 \mathrm{~h}, 0700 \mathrm{~h}$, and $1100 \mathrm{~h}$.

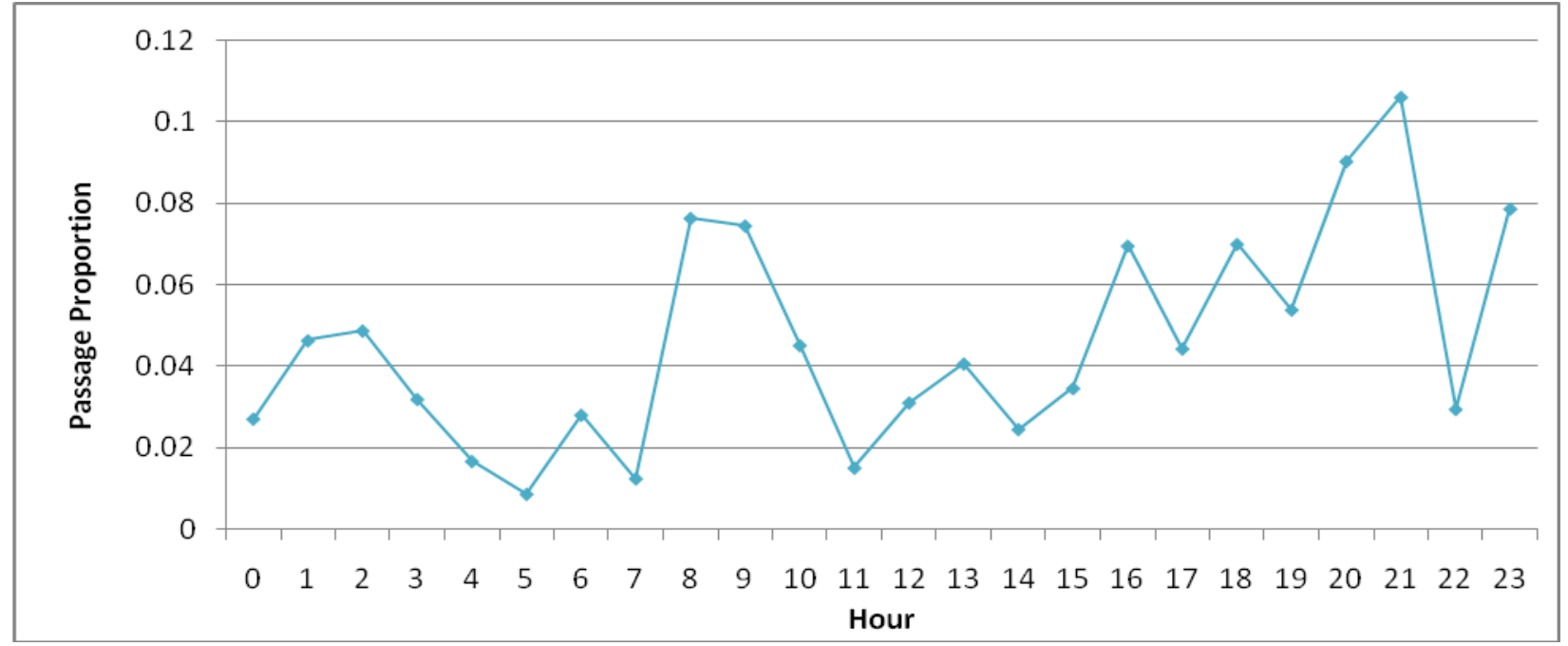

Figure 3.10. Diel Distribution of Overwintering Summer Steelhead and Kelt-Sized Targets from March 1-April 9, 2009. Data are the hourly proportions of total passage. 


\subsection{Fish Behavior Observations}

For both the overwintering steelhead and kelts, fish in front of the sluice entrance exhibited several behaviors. Generally, most fish were oriented into the flow in the sluice nearfield (Figure 3.9). Some were milling just upstream of the sill, while others passed downstream into the sluiceway. Other fish swam upstream out into the forebay. Steelhead were also observed moving along the face of the dam from sluice entrance 1-2 to sluice entrance 1-1 and vice versa.

Juvenile shad (Figure 3.11) were present from the beginning of the sampling period on November 1, 2008 until mid-November. Steelhead behavior did not seem to change despite the presence of thousands of juvenile shad migrating downstream into the sluiceway.

From late November to the end of the sampling period on December 15, schools of yearling-sized salmonids were observed in the DIDSON images (Figure 3.12). These fish were present in large schools at times and they used the sluiceway to pass downstream.

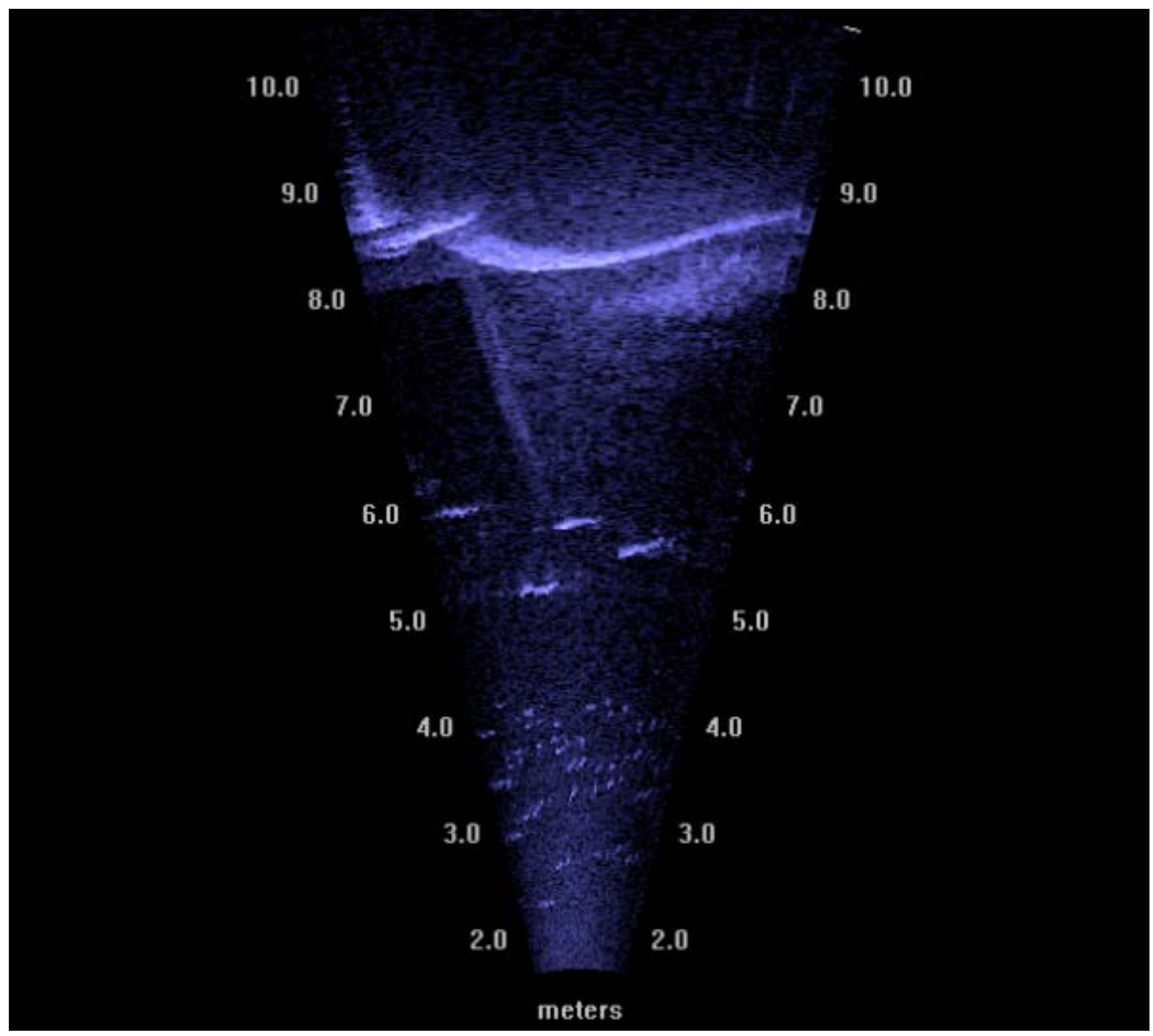

Figure 3.11. Adult Steelhead with Juvenile Shad During November 2008 at Sluice Entrance 1-1 


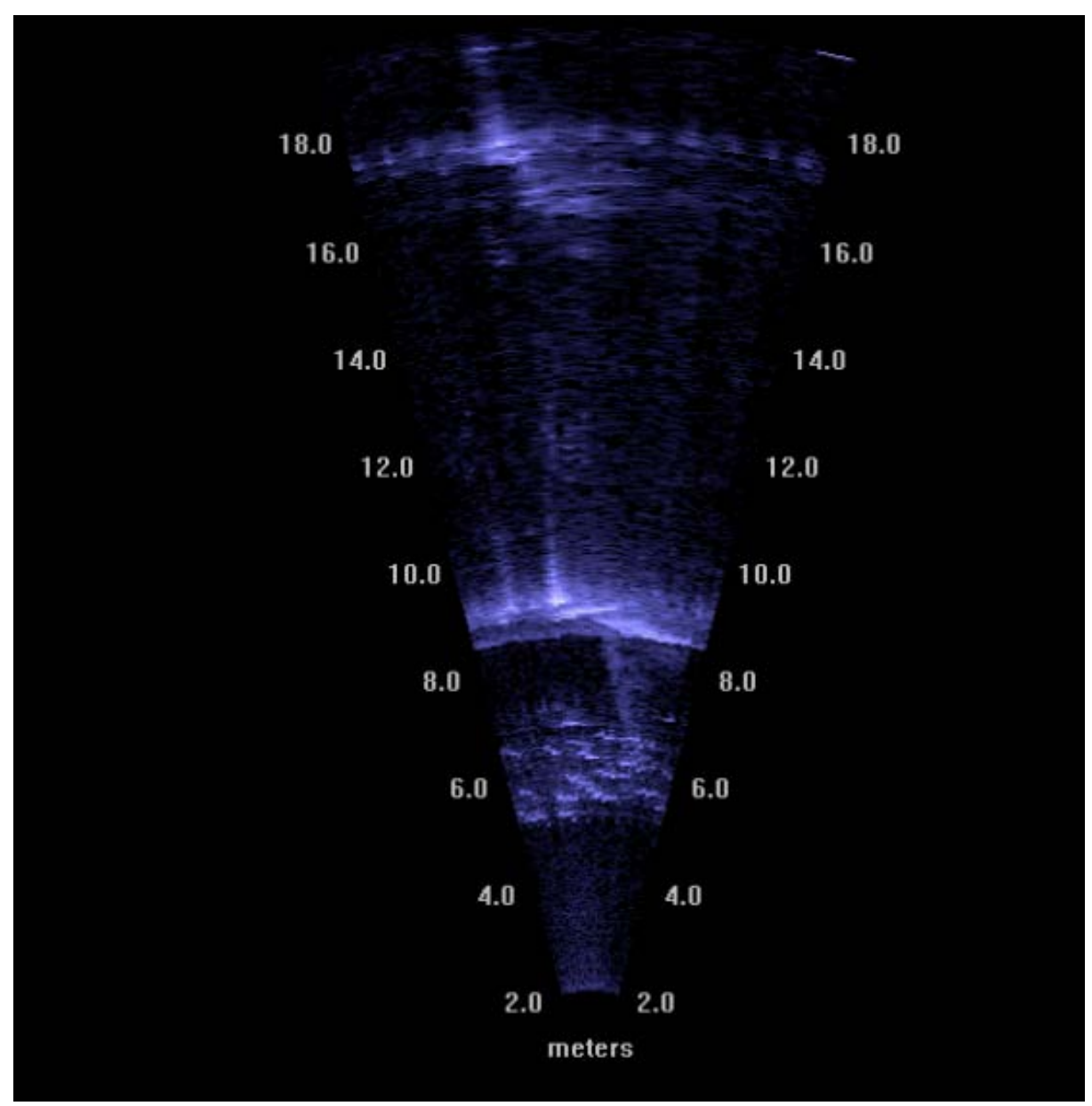

Figure 3.12. Yearling-Sized Salmonids During December 2008 at Sluice Entrance 1-1

After observing juvenile shad and yearling-sized fish targets during the fallback study in late fall, and knowing that some juvenile salmon emigrate in early spring, we analyzed the fixed-location hydroacoustic data to learn more about the run timing of juvenile fish during both study periods. For targets with mean target strengths between -36 and $-56 \mathrm{~dB}$, passage peaked in late fall during the first two weeks of November 2008 (Figure 3.13). Based on our DIDSON observations and beach seine samples 70 miles downstream (Sather et al. 2009), it is likely that these targets were almost entirely comprised of juvenile shad. The juvenile shad emigration was completed by the third week in November. Passage rates for juvenile fish were lowest during the last week of the fallback study (Figure 3.13). During early spring 2009, we observed high passage on four different dates that occurred early and late in the sampled period (Figure 3.14). Passage of juvenile fish was sporadic in early spring 2009. 


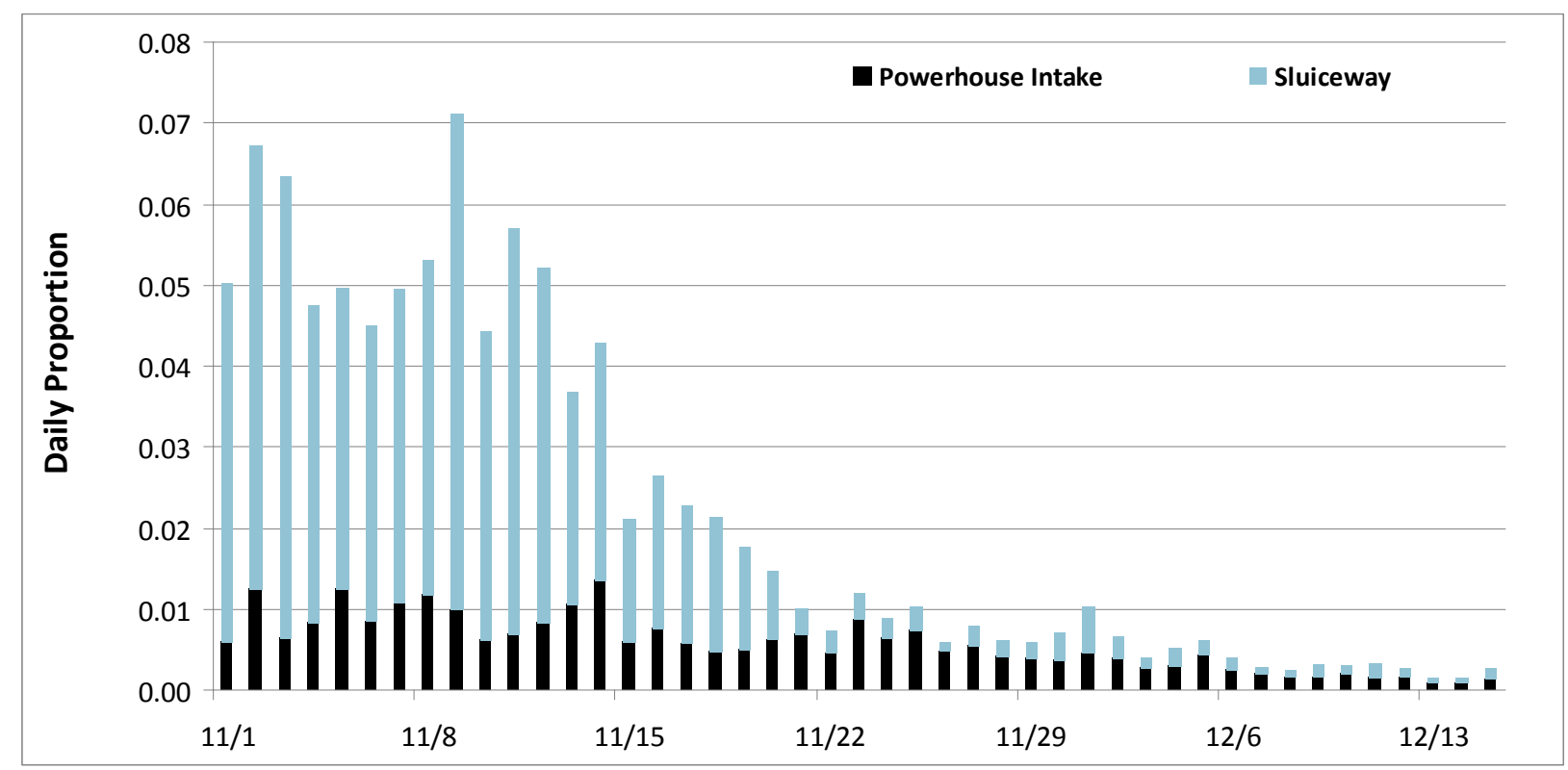

Figure 3.13. Run Timing for Juvenile Sized Fish During Late Fall 2008

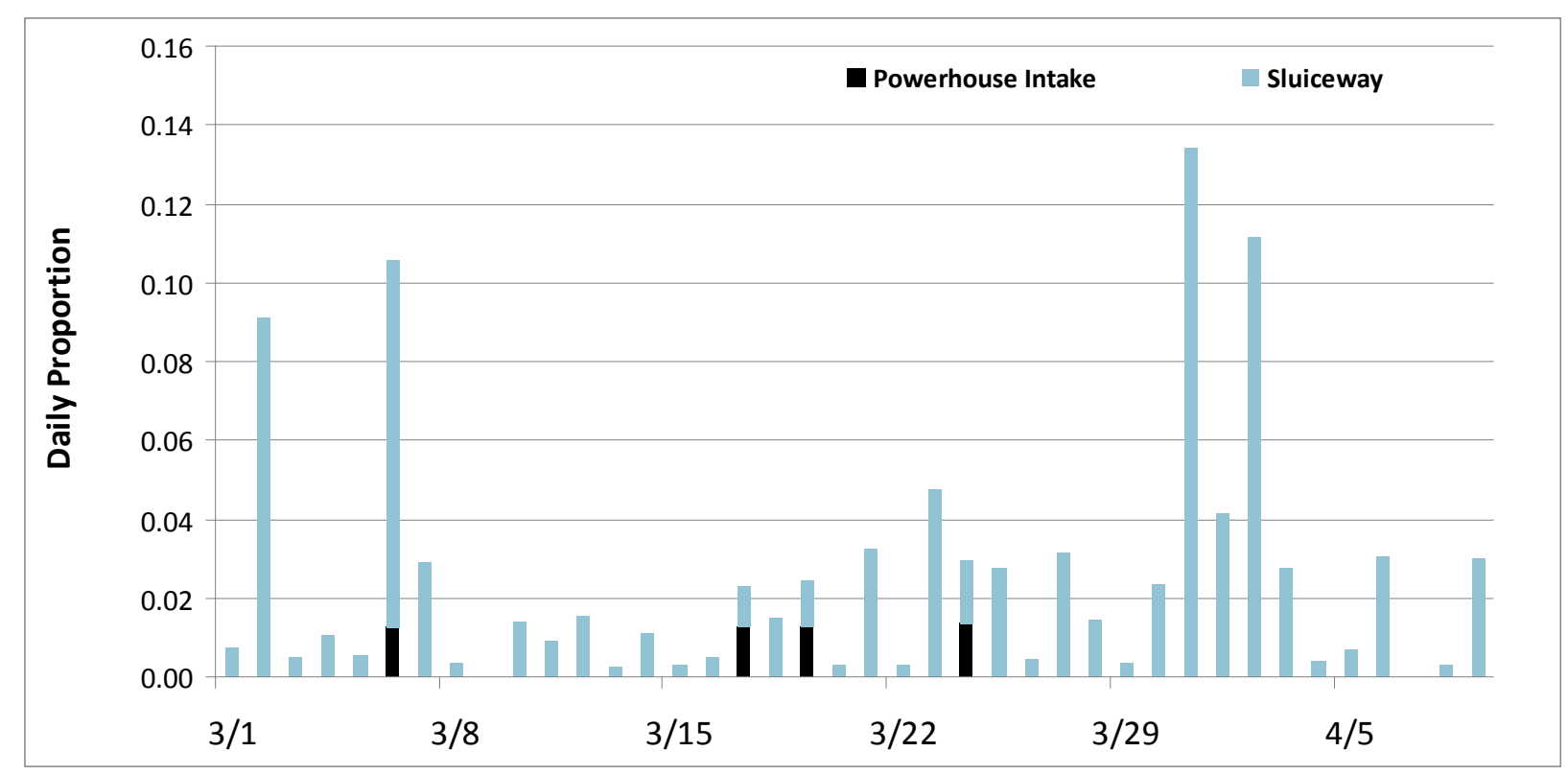

Figure 3.14. Run Timing for Juvenile Sized Fish During Early Spring 2009 


\subsection{Discussion and Conclusions}

We conducted a hydroacoustic study at TDA from November 1 to December 15, 2008, and from March 1 to April 9, 2009, to evaluate overwintering summer steelhead falling back through the dam in the fall and winter months and overwintering summer steelhead and early out-migrating steelhead kelt passage in the spring. The overall goal of this study was to provide information about steelhead fallback and kelt passage at TDA to support decisions on the operations of the sluiceway in winter and early spring months to allow fish passage through that route, thereby reducing turbine passage to improve steelhead survival as they pass the dam. The USACE included in its 2006 Fish Passage Plan operating the TDA sluiceway until November 30 as a route for steelhead falling back during migration because of concerns about these fish using the turbines as a route through the dam. Operating the sluiceway reduces the potential for hydropower production, but this surface flow outlet may be the optimal non-turbine route for fallbacks in the fall and winter months and kelt passage in early spring before the start of the spill season. Johnson and Dauble (2006) concluded that surface flow outlets are prime routes for passing downstream migrating juvenile salmonids at dams. The results of this study indicate that overwintering summer steelhead falling back during migration in the fall and winter months and kelts migrating downstream in the early spring used the sluiceway and some turbines as routes through the dam. Passage through the sluiceway far exceeded passage through turbines even though only a fraction of powerhouse flow went through the sluiceway.

For the overwintering summer steelhead, fallback occurred throughout the 45-day study period, except for December 9, when no steelhead targets apparently passed the dam. During this study, a total of $1,790 \pm 250$ (95\% CI) summer steelhead targets passed through the powerhouse intakes and operating sluices. Ninety-five percent (1,704 targets) of the total fish passed though the sluiceway. Therefore, without the sluiceway as a route through the dam, a number of steelhead may have fallen back through turbines. Run timing peaked in late November, but fish continued to pass the dam until the end of the study. Fallback occurred ( 13 fish/d) through the sluiceway during the last 2 days of the study period, indicating that these fish are still passing the dam in the middle of December. Horizontal distribution data indicated that Sluice 1 is the preferred route for these fish during fallback through the dam. For individual sluice entrances, sluice entrance 1-3 passed the highest number of fish (1,192 targets), followed by sluice entrance 1-2 (195) and sluice entrance 18-2 (122). Fewer than one hundred targets passed through sluice entrances 1-1, 5-2, and 18-1. Diel distribution for overwintering steelhead fallbacks was variable with no apparent distinct patterns. The lack of a clear trend in diel passage suggests that fish are passing at all times of a day. Therefore, sluiceway operations should not be based on diel distribution in fall and winter.

Overwintering summer steelhead and early out-migrating kelt passage occurred throughout the 40day spring study period, except for March 9 and April 7, when it appeared that no targets passed the dam. During this study, a total of 1,766 \pm 277 (95\% CI) steelhead adult-sized targets passed through the powerhouse intakes and operating sluices. Ninety-five percent (1,673 targets) of the total fish passed through the sluiceway. Therefore, not having the sluiceway as a route through the dam, a number of overwintering steelhead and out-migrating kelts may use the turbines for downstream passage before the start of the spill season. Run timing peaked in late March; however, relatively large numbers of adultsized targets passed the dam on March 2 and March 6 (162 and 188 fish, respectively). Horizontal distribution shows the highest passage occurred at Sluice 1 (62\% of total fish), followed by Sluice 18 (26\%), indicating that Sluice 1 is the preferred route for fish passage as they migrate downstream through 
the dam. For individual sluice entrances, sluice entrance 1-3 passed the highest number of fish (785 targets), followed by sluice entrance 18-1 (337) and sluice entrance 1-2 (205). Sluice entrances 5-2 and 18-2 passed 127 and 117 targets, respectively. Sluice entrance 1-1 passed the least amount of fish (101). A weak diel trend in passage was observed in early spring, and it suggested that passage was generally higher at $0700 \mathrm{~h}$ and $0800 \mathrm{~h}$ and from afternoon until midnight than it was at other hours. Nevertheless, the observed trend was not strong enough to proposing diel changes in sluiceway operation.

Fish behavior of both overwintering summer steelhead fallbacks and out-migrating kelts was that of a typical salmonid in front of a sluice entrance. Fish in front of the sluice entrance were oriented into the flow in the sluice nearfield, milling just upstream of the sill, entering into the sluiceway, or swimming upstream out into the forebay. These fish also moved along the face of the dam. Juvenile shad were present from the beginning of the sampling period on November 1, 2008, until mid-November. Steelhead behavior did not change in the presence of thousands of juvenile shad.

The results of this study strongly suggest that operating the TDA sluiceway for fish passage (fallbacks and kelts) during the late fall, winter, and early spring months will provide an optimal, non-turbine route for these fishes to pass the dam. Johnson et al. $(2005,2006)$ found the sluiceway to be an efficient and effective route for juvenile salmonids as they migrate downstream. The same may be said for overwintering summer steelhead falling back or kelts migrating downstream. Results from a study conducted by Boggs et al. (2004) indicated that steelhead fallbacks "overshot" their natal streams or hatcheries during upstream migration and after falling back, these fishes were found in streams and hatcheries below the fallback site. Kelts migrating to the ocean are capable of returning to their freshwater spawning grounds to spawn again, which is an important factor for maintaining stable steelhead populations in their native rivers (Wertheimer and Evans 2005; Wertheimer 2007). Fallback of overwintering summer steelhead during late fall and winter and passage of out-migrating kelt and overwintering steelhead during early spring are instances of the benefits of using surface flow outlets instead of turbines to pass salmonids. All 13 dams on the mainstem Columbia and Snake rivers have installed or are developing surface flow outlets to pass juvenile salmonids. Fisheries and hydrosystem managers are responsibly considering the use of these structures to protect adult salmonids from hydropower turbines (NMFS 2008). 


\subsection{Literature Cited}

Boggs CT, ML Keefer, CA Peery, TC Bjornn, and LC Stuehrenberg. 2004. "Fallback, Reascension, and Adjusted Fishway Escapement Estimates for Adult Chinook Salmon and Steelhead at Columbia and Snake River Dams.” Trans. Amer. Fish. Soc. 133:932-949.

Burwen DL and SJ Fleischman. 1998. "Evaluation of Side Aspect Target Strength and Pulse Width as Potential Hydroacoustic Discriminators of Fish Species in Rivers.” Can. J. Fish. Aquat. Sci. 55:24922502.

Carlson TJ, WC Acker, and DM Gaudet. 1981. Hydroacoustic Assessment of Downstream Migrant Salmon and Steelhead at Priest Rapids Dam in 1980. APL-UW 8016, Applied Physics Laboratory, University of Washington, Seattle, Washington.

Johnson GE. 2000. Assessment of the Acoustic Screen Model to Estimate Smolt Passage Rates at Dams: Case Study at The Dalles Dam in 1999. Final report submitted to Waterways Experiment Station, U.S. Army Corps of Engineers, Portland District, Portland, Oregon by BioAnalysts, Inc. Vancouver, Washington.

Johnson GE and DD Dauble. 2006. "Surface Flow Outlets to Protect Juvenile Salmonids Passing through Hydropower Dams.” Reviews in Fisheries Science 14:213-244.

Johnson GE, F Khan, JB Hedgepeth, RP Mueller, CL Rakowski, MR Richmond, JA Serkowski, and JR Skalski. 2006. Hydroacoustic Evaluation of Juvenile Salmonid at The Dalles Dam Sluiceway, 2005. PNNL-15540, final report submitted to the U.S. Army Corps of Engineers, Portland District, Portland, Oregon, by Pacific Northwest National Laboratory, Richland, Washington.

Johnson GE, ME Hanks, F Khan, CB Cook, JB Hedgepeth, RP Mueller, CL Rakowski, MR Richmond, SL Sargeant, JA Serkowski, and JR Skalski. 2005. Hydroacoustic Evaluation of Juvenile Salmonid Passage at The Dalles Dam in 2004. PNNL-15180, final report submitted to the U.S. Army Corps of Engineers, Portland District, Portland, Oregon, by Pacific Northwest National Laboratory, Richland, Washington.

Keefer ML and CA Peery. 2007. "Summary of Steelhead Fallback During November at The Dalles Dam.” Letter report prepared for the U.S. Army Corps of Engineers, Portland District, Portland, Oregon, by University of Idaho, College of Natural Resources. Moscow, Idaho.

Keefer ML, CT Boggs, CA Peery, and C Caudill. 2008. "Overwintering Distribution, Behavior, and Survival of Adult Summer Steelhead: Variability Among Columbia River Populations.” North American Journal of Fisheries Management 28:81-96.

MacLennan DN and EJ Simmonds. 1992. Fisheries Acoustics. Chapman and Hall, London.

National Marine Fisheries Service (NMFS). 2004. Endangered Species Act Status of West Coast Salmonids, June 17, 2004. NMFS, Northwest Region, Portland, Oregon. 
National Marine Fisheries Service (NMFS). 2008. Biological Opinion - Consultation on Remand for Operation of the Federal Columbia River Power System, 11 Bureau of Reclamation Projects in the Columbia Basin and ESA Section 10(a)(1)(A) Permit for Juvenile Fish Transportation Program. NMFS (National Oceanic and Atmospheric Administration Fisheries) - Northwest Region, Seattle, Washington.

Nealson PA and J Gregory. 2000. "Hydroacoustic Differentiation of Adult Atlantic Salmon and Aquatic Macrophytes in the River Wye, Wales.” Aquat. Living Resources 13:331-339.

Reischel TS and TC Bjornn. 2003. "Influence of Fishway Placement on Fallback of Adult Salmon at the Bonneville Dam on the Columbia River.” North American Journal of Fisheries Management 23:1215-1224.

Sather NK, GE Johnson, AJ Storch, DJ Teel, JR Skalski, TA Jones, EM Dawley, SA Zimmerman, AB Borde, C Mallette, and R Farr. 2009. Ecology of Juvenile Salmon in Shallow Tidal Freshwater Habitats in the Vicinity of the Sandy River Delta, Lower Columbia River, 2008. PNNL-18450, final report submitted to the Bonneville Power Administration by Pacific Northwest National Laboratory, Oregon Department of Fish and Wildlife, National Marine Fisheries Service, and University of Washington.

Thorne R and G Johnson. 1993. "A Review of Hydroacoustic Studies for Estimation of Salmonid Downriver Migration Past Hydroelectric Facilities on the Columbia and Snake Rivers in the 1980s.” Reviews in Fisheries Science 1:27-56.

Wertheimer RH, PL Madson, and MR Jonas. 2003. Evaluation of Steelhead Kelt Project Abundance, Condition, Passage, and Conversion Rates Through Lower Columbia River Dams in 2002. U.S. Army Corps of Engineers, Portland District Fish Field Unit, Bonneville Lock and Dam, Cascade Locks, Oregon.

Wertheimer RH and AF Evans. 2005. "Downstream Passage of Steelhead Kelts through Hydroelectric Dams on the Lower Snake and Columbia Rivers.” Trans. Amer. Fish. Soc. 134:853-865.

Wertheimer RH. 2007. "Evaluation of a Surface Flow Bypass System for Steelhead Kelt Passage at Bonneville Dam, Washington.” North American Journal of Fisheries Management 27:21-29. 


\section{Distribution}

No. of

Copies

OFFSITE

8 David Clugston

U.S. Army Corps of Engineers

P.O. Box 2946

Portland, OR 97208
No. of

Copies

\section{ONSITE}

5 Pacific Northwest National Laboratory

KD Ham

K6-85

GE Johnson

F Khan

BPO

GR Ploskey

K6-85

MA Weiland
NBON

NBON 


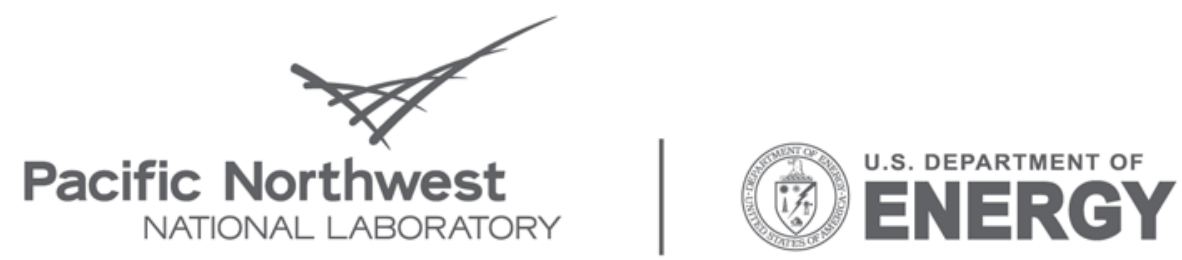

Proudly Operated by Battelle Since 1965

902 Battelle Boulevard

P.O. Box 999

Richland, WA 99352

1-888-375-PNNL (7665)

www.pnl.gov 